University of Louisville

ThinkIR: The University of Louisville's Institutional Repository

Electronic Theses and Dissertations

$12-1992$

\title{
Pope Clement VI : attempts to resurrect the papal monarchy.
}

Henry Miles Spalding 1961-

University of Louisville

Follow this and additional works at: https://ir.library.louisville.edu/etd

\section{Recommended Citation}

Spalding, Henry Miles 1961-, "Pope Clement VI : attempts to resurrect the papal monarchy." (1992). Electronic Theses and Dissertations. Paper 1362.

https://doi.org/10.18297/etd/1362

This Master's Thesis is brought to you for free and open access by ThinkIR: The University of Louisville's Institutional Repository. It has been accepted for inclusion in Electronic Theses and Dissertations by an authorized administrator of ThinkIR: The University of Louisville's Institutional Repository. This title appears here courtesy of the author, who has retained all other copyrights. For more information, please contact thinkir@louisville.edu. 


\author{
POPE CLEMENT VI \\ Attempts to Resurrect the Papal Monarchy
}

By

Henry Miles Spalding

B.A., University of Louisville, 1989

\author{
A Thesis \\ Submitted to the Faculty of the \\ Graduate School of the University of Louisville \\ in Partial Fulfillment of the Requirements \\ for the Degree of
}

$$
\text { Master of Arts }
$$

\footnotetext{
Department of History University of Louisville Louisville, Kentucky
}

December 1992 


\author{
POPE CLEMENT VI \\ Attempts to Resurrect the Papal Monarchy \\ By \\ Henry Miles Spalding \\ B.A., University of Louisville, 1989
}

A Thesis Approved on

$\frac{7 \text { Dember } 1992}{\text { (Date) }}$

by the following Reading Committee:

Thesis Director 


\section{ABSTRACT}

The papacy of Clement VI (1342-1352) was distinguished by its political activism, its attempt to resurrect the impetus for crusading, and its efforts to attract the best and brightest talents to Avignon. The attributes which characterize his pontificate highlight his interest in resurrecting the papal monarchy. His political conservatism was manifested most vividly in his struggles with the German emperors Louis IV and Charles IV. Clement VI asserted that papal auctoritas superseded temporal imperium. Canonistic and publicists arguments were alloyed with clement's own unique views to stem the loss of the papacy's secular power. Clement VI's political dynamism was also displayed in renewed efforts to create an expeditionary force to wage a holy war against the Muslims. His Smyrna Crusade and Holy League achieved the last resurgence of western Christian influence in the Levant in the Middle Ages. Finally, the intellectual legacy of $\mathrm{Clement} V I$ is one of humanistic involvement. In the pontificate of $\mathrm{Clement} V I$ can be found the seeds of Renaissance humanism, represented by realistic art forms, a rebirth of classical literature, and the presence of humanist scholars at the papal court. Confined by the realities of the Anglo-French war and the Black Death, Clement VI was able to achieve only limited results. 
TABLE OF CONTENTS

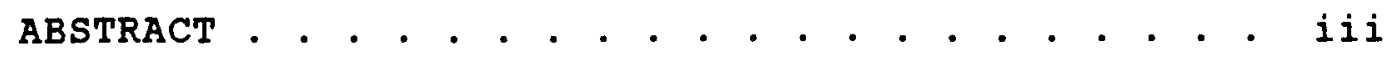

INTRODUCTION . . . . . . . . . . . . . . . . . . . . 1

CHAPTER

I. DEVELOPMENT OF THE DOCTRINE OF TWO SWORDS . 9

I I. POPE CLEMENT VI AND THE GERMAN EMPERORS:

PAPAL AUTHORITY VERSUS IMPERIAL RIGHTS . . . 39

III. POPE CLEMENT VI'S IDEA OF CRUSADE AND ITS

PRACTICALITY . . . . . . . . . . . . . . 72

IV. CLEMENT VI: PROTO-RENAISSANCE POPE

$(1342-1352)$. . . . . . . . . . . . . 116

CONCLUSION . . . . . . . . . . . . . . . . 153

GLOSSARY . . . . . . . . . . . . . . . . . . 157

BIBLIOGRAPHY . . . . . . . . . . . . . . . . 158

VITA . . . . . . . . . . . . . . . . 163
\end{abstract}




\section{INTRODUCTION}

The fourteenth century stands out in the annals of history as one of calamity and dislocation. Cursory readings of this time befuddle the reader to the point of amazement that any task was completed at all. Was this not the century in which the epic confrontation known as the Hundred Years War began? Did not the Catholic consensus receive the strongest test to its authority in the fourteenth century? What more horrific specter has man faced than the Black Death? Interspersed among these enormous dislocations were lesser known, but similarly divisive events, like the widespread famines of the early fourteenth century, the crash of Italian banking, and the well known social uprisings that sprang up, as if in unison, known as the revolt of the Ciompi in Italy, the Jacquerie in France, and the Peasants' Revolt in England. The foundations of Medieval unity were severely shaken by the impact of these calamities. In fact, one would search in vain to find an area where none of the above afflictions was familiar to the common man in a personal sense.

No aspect of the human experience in western Europe went untouched by the continuous upheavals of the fourteenth century. The one monolithic institution which, heretofore, had resisted great change, and provided a model of stability, was the Roman Catholic Church. But even the Church experienced a painful metamorphosis during this 
period. In what has been called the last great attempt of the papacy to assert temporal authority, Boniface waged a long war with Philip IV over the right of France to tax the Church.

The century prior to the fourteenth was a time of consolidation of power for the church in general, and the papacy in particular. The strides of popes like Innocent III, Gregory IX, and Innocent IV in the temporal realm, propelled the church to ever greater heights. The abilities of the great popes of the thirteenth century must be recognized in relationship to their secular counterparts. The thirteenth century was blessed with the long reigns of two intelligent and pious kings, Louis IX of France and Henry II of England. Though differing in ability, their magnaminity toward the church was equal. The only trenchant obstacle to papal dominion in the thirteenth century was the Holy Roman Emperor, Frederick II. The struggle between the papacy and the emperor was finally resolved with Frederick I being deposed and the imperial office losing much of its power and usefulness.

The last third of the thirteenth century saw a gradual resurgence of secular power in relation to papal power. The reigns of Edward I of England and Philip III of France acted much more independently of the papacy. Edward I, the more original thinker of the two, did much to unite England and its hinterlands. His statute of Mortmain limited the influence of foreign powers like the Church from acquiring 
lands in England. Though not saintly, Philip III was beholden to the Church, and even acted as its temporal arm against the Aragonese and Italians. While returning from a war initiated by the pope, he lost his life. The emergence of his son, Philip IV, as the next great French monarch proved, ultimately, detrimental to papal power.

Faced with the renewed vigor of the French monarchy, the papacy was forced to assert its authority more fully. So bewildering had the complexities of the papal office become, that Pope Celestine V resigned the office after only five months. This set the tone for the freefall of papal prestige.

The election of Boniface VIII to the papacy was logical to the college of cardinals in many ways. He was administratively qualified, thoroughly authoritative, and competent in canonical matters. These very attributes, which elevated the reign of many thirteenth century popes, were ill-suited to the political realities of the fourteenth century. Gone were the days when the papacy could demand increased taxation, and further, appoint men to the important bishoprics of England and France. Indicative of this fact was Boniface VIII's attempt to tax the clergy of France and England.

When Boniface issued the bull Clericis Laicos, which stated the right of the Church to tax, he set in motion the dynamics of a new and far reaching conflict between church and state. Philip IV, realizing the importance of French 
money to the solvency of the papacy, closed the borders of France to the export of gold or silver. Boniface was forced to back down. He surrendered to Philip IV the right to tax the clergy of France for extraordinary reasons. Another conflict arose in 1301, when Pope Boniface refused to back Philip's attempt to discipline the bishop of Pamiers. Boniface recognized it as an attempt to breach a sacred agreement between Church and state, the right to reprimand a member of one's own flock. In November of 1302, Boniface VIII issued the bull, Unam Sanctam. This bull proclaimed that papal authority held supremacy over temporal power. It was ill-timed, unrealistic, and inflammatory to issues at hand. A propaganda war began. King Philip IV, under the advice of William of Nogaret, forged allegations against Boniface questioning his qualifications and piety. The matter was resolved in violent fashion. Nogaret, with several of his henchmen, kidnapped and assaulted Boniface in the Italian town of Anagni in 1303. Boniface died soon afterward.

The papacy was thoroughly humiliated by Philip IV's tour de force. The humiliation was compounded by the fact that Rome had become simply uninhabitable for the papacy. The competing patrician families of Rome had reduced the city to chaos. Less than one hundred years after the papacy had reached its apogee, it plummeted to its greatest depths. With little support in Rome, the papacy and the curia began a sojourn through Italy to southern France. It wandered 
about for four years, finally settling in Avignon in 1309 . In the interim, the cardinals elected the short lived Benedict XI (1303-1304), and then Pope Clement V (13051314). Clement $V$ had every intention of returning to Rome, but on the insistence of Philip IV and a French dominated college of cardinals, he stayed in France, but he never lost sight of his roots. A popular conception was that the papacy was controlled by the French king. A result of this was that the papacy could not rely on much help outside France when it came to formulating and executing its programs.

Similar situations confronted Clement's successor, Pope John XXII (1316-1334). John XXII's papacy was one of political and economic consolidation. John undoubtedly believed that new attacks on the church and the papacy were an inevitable response to its weakened state. Therefore, we do not see John dealing with theological dissent in a conservative manner. His attacks against the spiritual Franciscans over Apostolic poverty, his peculiar notions on the Beatific Vision, and his issuance of the Extravagantes helped present the image of a rebounding papacy. Political realities like his troubles with the deposed Lewis IV, denied John XXII the luxury of declaring outright success. In actuality, the papacy remained on the defensive.

Concurrent with the reemergence of the papacy, was the strengthening of nationalistic tendencies. With this immature nationalism came increased hostilities between 
nations. The fourteenth century witnessed a complex ordering of alliances and counter-alliances. These political compacts involved France, the kingdoms of spain, the Low Countries, England, and Scotland. The major conflicts which arose in the fourteenth century usually entailed the participation of these countries. When Edward II of England asserted his right to the French crown in 1337, this ignited the powder keg known as the Hundred Years War. The devastation and havoc caused by the early period of this confrontation affected every aspect of French and English society. While Avignon was nestled in southern France, it did not escape the economic and political problems caused by the French and English war.

In 1291, the last vestige of French influence in the Levant ended with the fall of Acre. The proto-humanist Dante was beginning to discover his literary abilities. 1291 also marked the death of Rudolf I of Hapsburg, a man who strived in vain to receive the papal approbation needed to be rightly proclaimed emperor. This same year marked the birth of Pierre Roger in the region of Corrèze. He was born the son of Guillaume Roger, of minor nobility. At the age of ten, he was sent to the Benedictine monastery at ChaiseDieu in southern France. Pierre received permission to go to Paris to be educated. He received his doctorate in theology in 1323 .

As a sign of his talents, he received rapid ecclesiastical promotions. Thanks to the support of both Pope John 
XXII and King Philip VI of France, he was granted the prized bishopric of Arras in 1328, and the archbishoprics of sens in 1329, and Rouen in 1330 .

Pierre Roger was elected pope on the 7 th of May, 1342. Clement VI owed his election as much to the lobbying of Philip VI and the support of those Cardinals who had labored under the stern and abstemious Benedict XII, as to his own intellectual and oratorical skills. He immediately began to expand the power of the papacy. His hands-on approach to administering his office had several results. Clement VI granted benefices and expectancies at unprecedented rates. This served a two fold purpose. By granting ecclesiastical posts himself, he took that power away from the secular lords who were accustomed to granting this privilege. It also increased revenues to the papal treasury. Clement tried to extend papal power in the political arena as well. He played a large role in the truce of Malestroit between France and England in 1343. Clement attempted to bolster papal power in Italy. In addition, he started the early planning for a crusade in the East. Lastly, he resolved to bring the struggle with the Holy Roman Emperor to an end. The effect of the Black Death on the later days of his reign were strong. The church lost needed revenues. It was forced to spend more on relief for the suffering. To survive this period was fortunate, but to flourish, as the papacy seemingly did, was inconceivable. All these successes were produced at a great cost. The papacy in 
Avignon never again realized the heights that clement achieved, partially because of the wastefulness of Clement's reign, but also because of the great upheavals of the fourteenth century. 
CHAPTER I

DEVELOPMENT OF DOCTRINE OF TWO SWORDS

The most enduring events of Pope Clement VI's reign were political in nature. Gifted with a sharp mind and capacious oratorical abilities, rarely was he found on the sidelines when some perceived injustice or infringement of papal rights emerged. Clement VI's political activism is evidenced by his interest in the monumental struggle between France and England in the fourteenth century. His proactive stance is also confirmed by his meddling in Italian politics, as he fought for the ambitious Joanna of Naples and against the cities in northern Italy. His most lasting political preoccupation, however, was with Lewis of Bavaria, who struggled against the Avignon papacy to gain recognition and approbation as emperor of the Holy Roman Empire.

The focus of this research is to outline the intricacies and developments of clement VI's struggle with Lewis of Bavaria and his promotion of Charles of Moravia. No study of this kind is possible without a careful treatment of the ideological and historical underpinnings supporting each faction's claims. The church/state contest worked on several levels. On one level, the struggle revolved around different understandings of papal auctoritas and temporal imperium. On another level, it stretched the conception of caesaro-papism* against ecclesiastical 
hierarchy. Also involved were theories on dualistic power structures opposing a monolithic one, or at the simplest level, the battle between two dynamic personalities. What elevates the struggle between Clement VI and Lewis IV above the common conflicts between these two spheres were the different levels of confrontation coming into play.

The kinds of church/state problems which clement VI was forced to contend with were inherited from preceding popes. The particular conflict which we are concerned with was only another installment, or rather another layer of theoretical accretions in this highest realm of medieval confrontation. The battle with Lewis of Bavaria was inherited in the strictest sense of the word. The initial tinderbox was ignited by Lewis of Bavaria's controversial election over Frederick, Duke of Austria. Shortly after the election of Pope John XXII, following two years without a pope, an attempt was made by the newly-elected pontiff to chose between the rival imperial candidates. Obstinacy on the part of the candidates obfuscated the issue and prevented any success in negotiations. The strength of Lewis IV's military forces ended Frederick of Austria's attempts to become emperor. Lewis IV became emperor de facto, but in John XXII's eyes, not de iure. Thus the battle lines were drawn. Enemies of John XXII fled to Lewis IV's court, further increasing enmity between the opposing factions. In addition to Lewis' contested election, he never received the papal approbation, which traditionally 
made one truly the king of the Romans.

With the emasculation of the imperial office by the papacy in the thirteenth century, succeeding popes became accustomed to directing the emperor's actions in the secular arena, especially in Italy. It was with predictable indignation and incredulity that first John XXII, and then Clement VI, received news of Lewis' continual assertions of imperial autonomy. With the exception of the interregnum of Benedict XII, the period between 1318-1352 is marked by an exceedingly wasteful use of intel lectual and political energy to reclaim the thirteenth century political arrangement between pope and emperor.

To avoid begging the question, "What was the thirteenth century arrangement?" we must briefly explore not only the thirteenth century, but also the preceding centuries of political evolution between church/state.

The struggle between the state and the Christian Church finds its genesis in the first century C.E. The underlying impetus for this kind of struggle has existed since the invention of states and amphictyonies. Historically, wherever the two entities exist in close proximity, one is subordinate to the other. Much has been written lauding the attributes of both arrangements.

Historical precedent was employed equally by both sides in the confrontation between Christians and the state. Descendants of Roman imperial dignity recalled openly their early political supremacy. Early Christian theorists relied 
more on New Testament interpretation and their Judaic understanding. The resulting debates between the two political entities seem like streams running parallel to each other, never meeting or conforming, but remaining close enough so as to affect the other. An inspection of early imperial and spiritual arguments provides a necessary perspective for the imperial/papal struggle of the midfourteenth century.

The primary early source for imperial authority was derived from Aristotle. Aristotle declared that man is by nature a political creature, that the state is therefore a logical extension of his creative gifts, granted by God for the good of all men. 1

Another tenet of Aristotle was that there was a natural inequality among men. His political theories on authority assert that while power is derived from the people, some men are better equipped to wield it. Aristotle pointed out that while authority rests with the people, verily it is useless if it is a slave to factionalism or diffusion.?

To Aristotle, the highest authority was held by those most virtuous. Thus, the highest authority was wielded by men, families, or factions, who were supreme in virtue. The implications of this theory were striking, because they lent themselves to vague interpretation and moral obfuscation.

\footnotetext{
'Aristotle Politica 1.1253a.6-20.

'Ibid. , 3.1278b.14-37.
} 
If authority rested with the people, then one method of channeling the energy of the masses was through popular representation. The Athenians exercised and experimented with this method of governing in the form of the senate. In the senate, the people had a "mouth piece." In reality, the senate pursued an elitist agenda, but ideally, it represented the will of the people. The Athenian senate, at its height, was composed of several assemblies, which were honor bound to protect the rights of all people. Authority was exercised by rich and poor alike, in judicial, as well as administrative matters.

The early Roman Republic was born out of similar impetus. Profiting from the example of the Greeks, Roman law makers realized the inequalities promoted by monarchy. Legislation was enacted that blunted the efforts of men who would be king. Livy tells how the Roman people bound themselves to an oath, "never to allow any man to be king in Rome." Early legislation was designed to give greater authority to the senate. ${ }^{3}$

The history of Rome is one of military confrontation. For this reason, the office of consul was created, first for military purposes, then it went on to acquire executive functions. Cicero and Polybius indicate that imperial

'Livy, The Early History of Rome, eds., Robert Baldick and Betty Radice (London: Hazell Watson \& Viney, 1974), 102 . 
auctoritas finds its Roman roots in consular auctoritas. 4

With the rise of the Principate, we see a continuation of the notion of popular authority being supreme. This is evidenced by the fact that only the people could enact laws. ${ }^{5}$ No document exist which unequivocally state that the emperor was outside of law. ${ }^{6}$ Less than one hundred years after the inception of the Principate, in the time of the famous stoic seneca, we find the unspoken realization that the emperor is above the law, and the only limits placed upon him are his own personal limits.?

In this age of superstition, the cult of the emperor seemed right, proper and beneficial. The commanding stature of the imperial office and its seeming universality, spawned the mythical idea of emperor as potent god. This idea is interwoven into the Corpus Juris Civilis of the sixth century. We learn from Roman codices that while the people are the ultimate source of law, the emperor is the actual source of law.8

With the rise of Christianity, and the important role

${ }^{4}$ Charles H. McIlwain, The Growth of Political Thought in the West: From the Greeks to the End of the Middle Ages (New York: The MacMilitian Co., 1963), 135.

${ }^{5}$ Ibid.

${ }^{6}$ Ibid., 136 .

Tacitus, The Annals of Imperial Rome ed. Betty Radice, trans. Michael Grant (New York: Viking Penguin, 1989), 360-398 passim.

${ }^{8}$ McIlwain, 128 . 
of the emperor in its ascendancy, a phenomenon known as Caesaro-papism evolved in the Eastern half of the Empire. This phenomenon blended royal and sacerdotal powers into a single office. This politico-religious precedence set in the sixth century provided an important antecedent for later imperial legalist in the West.

Many early Christian writers ceded ecclesiastical rights to the emperor. Some went so far as to grant that his authority was direct from God. St. Optatus in the early fourth century defended the autonomous nature of the emperor. He stated that "the Empire is not in the Church, the Church is in the Empire, and that there is no one over the Emperor but God only, who made him Emperor." 9 In Ambrosiaster's writings, we see the Emperor called "vicarius Dei," Later, he extended the vicarial analogy to the point that the emperor has "the image of God as the Bishop has that of Christ."10 To justify God's favor upon the emperor, many early Christians believed that the office was divinely ordained, not the man occupying it. Therefore, it was possible to have an evil emperor by God's providence.

The most quoted of early Church fathers on the subject of imperium by pro-imperial legalists was Pope Gregory I. According to Pope Gregory the Great, "(the emperor) must be

${ }^{9}$ Robert Warrant and Alexander James Carlyle, The History of Mediaeval Political Theory, vol. 1, 3d ed. (London: William Blackwood \& Sons), 148 .

${ }^{10}$ Ibid., 149 . 
reverenced as one who derives his authority from God."ll st. Gregory's imperial theory is peculiar unto himself, in both degree and conviction. As with most early thought on imperial maiestas, * the old Testament is the central font of evidence. The general view of Gregory I was that positions of power were divinely ordained. Potestas* was given not just to the emperor, but to all people to varying degrees in positions of leadership, because all power comes from God. Gregory I pointed out that since the emperor derives his power directly from God, then he has an obligations to God. He is shackled with the onus of ruling justly always, because he is answerable to God for any injustices perpetrated on his subjects. 12

The demands of early christians for independence from the state in spiritual matters was a frequent occurrence. There was also a general compulsion for declaring secular independence from the state. For various reasons, the emperor often felt obliged to get involved in church affairs and claimed a degree of authority in this area. One need look no further for proof than the right of emperors to call councils in the fourth century.

Early Christian writers had no idea that their words would be taken so literally, or employed in such diverse and unimaginable ways by later scholars. Most early Christian

${ }^{11}$ Ibid. , 152 .

${ }^{12}$ Ibid. , 123. 
writers had no solid conceptual theory on the right relationship of pope and emperor. That issue seemed secondary and less urgent when compared to purely spiritual matters.

The insights of St. Cyprian on the correct relationship of church and state were of great importance to the debate. His ideas were later construed to support both sides of the dispute. Cyprian's views on the primacy of Peter are cogent when studied exegetically, but when skewed to fit later medieval confrontations between church and state, they become quite confusing. Cyprian repeatedly quoted Matthew's Gospel recounting Jesus' word to Peter,

And I tell you, you are Peter, and on this rock I will build my church, and the powers of death shall not prevail against it. I will give you the keys of heaven, and whatever you bind on earth shall be bound in heaven, and whatever you loose on earth shall be loosed in heaven.

On the unity of the church, Cyprian tended to dilute to a degree the preeminence of Peter's power. In the tract De Catholicae Ecclesiae Unitate, he wrote "Upon one he [Christ] builds the Church, ...to all the apostles, he gives an equal power." and, Christ gave "equal fellowship both of honor and of power."14 Cyprian yields the attribute of architect to Peter, but not to the degree that Peter is distinguished by some supreme gift over the other apostles,

${ }^{13}$ Matt. $16: 18-19$.

14 E. Giles, ed., Documents Illustrating Papal Authority, A.D. 96-454, (London: William Clowes Sons, 1952), 51. 
and their subsequent bishops.

The friction which existed between the Christian Church and state was caused by opposition of the perceived missions of both entities. Officially, the Roman law did not allow any religion other than the state religion. Actually, there was a fairly large degree of religious freedom. This is suggested by the toleration of Judaism and other provincial religions. Indeed, the policies of toleration were an ever evolving process. One need only read the correspondence of Pliny the Younger to Trajan to see the ambiguities present in the law. 15

When Constantine and Licinius agreed on a policy of toleration in 311 C.E., many Christians had new reason to argue. Several Christian writers questioned the virtue of accepting any state support for their group which had traditionally been sectarian in nature.

St. Augustine of Hippo struggled with this problem. He claimed that the state was unnatural and unnecessary. He suggested that man should look toward and prepare for the coming of the city of God. Aristotle's notions about man as a political creature were rebuked. Thus, much of the political story of the Middle Ages is founded on the attempts of medieval scholars to reconcile the fundamental problems of this temporal/spiritual dualism by searching for

${ }^{15}$ Pliny the Younger, The Letters of the Younger Pliny, trans. and ed., Betty Radice (London: Cox \& Wyman, 1986), 29395 . 
compromise in unity. Augustine writes,

Every ordering of a human community must appear as a component part of that ordering of the world which exists because God exists, and every earthly group must appear as an organic member of that Civitas Dei, that God-state which comprehends the heavens and the earth. Then, on the other hand, the eternal and other-worldly aim and object of every individual man must, in a direct or an indirect fashion, determine the aim and object of every group into which he enters.

The new partnership required an updated set of rules.

It is out of this milieu that Christian writers like st.

Jerome, st. Augustine and st. Ambrose rose. An epistle,

which typifies the political writings of these men, was

composed by st. Ambrose. It was addressed to Emperor

Valentinian II, and it spelled out the limits of secular

power. In arguing for the autonomy of the church he said,

"In a matter I say of faith -- bishops are wont to judge of

Christian emperors, not emperors of bishops."17 The

Carlyles state in their magnum opus The History of Medieval

Political Thought,

We do not find in the Fathers the consciousness that the church has its own 1 aws and principles, its own administrative authority, which is not at all to be regarded as dependent upon the state, but as something which stands beside it and is independent of it.. . . tho
independent though closely related powers.

${ }^{16}$ otto Gierke, Political Theories of the Middle Ages trans. Frederic William Maitland (New York: Cambridge University Press, 1987), 7-8.

${ }^{17}$ Brian Tierney, ed., The Middle Ages, vol. 1, Sources of Medieval History, 4 th ed. (New York: Alfred A. Knopf, 1983), 25 .

${ }^{18}$ Carlyle, 176. 
One of the strongest proponents of ecclesiastical power was Pope Gelasius I. In a letter to Emperor Anastasius in 494, Gelasius asserted that there are two Powers which rule the world, sacred authority [auctoritas]* and kingly power

[potestas]. He went on to say,

of these the responsibility of the priest is more weighty in so far as they will answer for the kings of men themselves at the divine judgment. You know, most clement son, that, although you take precedence over all mankind in dignity, nevertheless you piously bow the neck to those who have charge of divine affairs and seek from them the means of your salvation, and hence you realize that, in the order of religion, in matters concerning the reception and right administration of the heavenly sacraments, you ought to submit yourself rather than rule, and that in these matters you should depend on their judgment rather than seek to bend them to your will. For if the bishops themselves, recognizing that the imperial office was conferred on you by divine disposition, obey your laws so far as the sphere of public order is concerned lest they seem to obstruct your decrees in mundane matters ... As Your Piety is certainly well aware, no one can ever raise himself by purely human means to the privilege and place of him whom the voice of Christ has set before all, whom the church has always venerated and held in devotion as its primate. The things which are established by divine judgement can be assailed by human presumption; they cannot be overthrown by anyone's power. 19

Pope Gelasius I echoed and magnified this sentiment when he expressed the belief that the secular ruler of men is subordinate to God. "He has privileges of his power which he has obtained by the will of God for the sake of public administration." 20 These assertions were intended to stop

\footnotetext{
${ }^{19}$ Tierney, 29-30.

${ }^{20}$ McIlwain, 164.
} 
any encroachment on spiritual power by secular authorities. They were not designed to claim any secular authority for the bishops. Gelasius and Ambrose were concerned that the distinction between the two spheres be made quite clear.

The growing influence of the northern Germanic tribes on Roman civilization led to a disruption of governmental structures and laws. The breach left by the vacating Roman bureaucracy was filled in some respects by the Church. The pope took on a more secular role out of necessity for the Church's existence. Their are numerous examples of secularminded popes negotiating with tribal rulers in the dark period between 450 C.E. to 800 C.E.

The increasing political strength of the pontiff is evidenced by an incident in 750 C.E. Pope Zacharias championed Pepin in his attempt to overthrow the last Merovingian ruler, Childeric III. Zacharias supported his action by reasoning that it was more logical to support the actual ruler of the Franks, than one who held the title, but nothing more. ${ }^{21}$

With the rise of Charlemagne in the late eighth century, we have documentation which illumines the complexities of church/state relations. Two important formulas which figured prominently in the struggle between Pope Clement VI and Lewis IV of Bavaria in the fourteenth century, find their genesis in this period. The first deals

${ }^{21}$ J.N.D. Kelly, The Oxford Dictionary of Popes (New York: oxford University Press, 1989), 90. 
with the privilege of the pope to anoint and crown the emperor. These rites were performed by Pope Leo III for Charlemagne in the year 800 . The second formula that arose from Charlemagne's ascension to the imperial throne was the regularizing or acceptance of "election" to the post.

Canonists of the twelfth and thirteenth centuries presented the example of Leo III crowning Charlemagne to support their theories of papal suzerainty. They also believed that this event provided indisputable historical precedent for imperial elections. In addition, and more importantly, their ability to anoint and crown the emperor illustrated the superiority of the pope, because charlemagne was not king of the Romans until Leo III translated the conception of imperium* from the East, and decreed it upon a Western ruler. Therefore, the station of priest is higher than that of prince, because it is the priest who consecrates the prince. ${ }^{22}$ Further examination of the coronation demonstrates clearly that Charlemagne was the more potent force in this situation, and that he was not duped as suggested by Einhard. ${ }^{23}$ Rather, he was aware of the Pope's plans and allowed Leo III the honor of crowning and anointing him, as a show of support for Leo's diminishing authority in Italy. ${ }^{24}$

${ }^{22}$ Carlyle, 256.

${ }^{23}$ Einhard, Two Lives of Charlemagne trans. Lewis Thorpe (New York: Viking Penguin, 1969), 81 .

${ }^{24} \mathrm{Kell} \mathrm{Y}, 98$. 
Through the primacy of the Roman pontiff and the supremacy of his consecration, it was argued, the western emperor was elevated above the eastern emperor. The power to translate imperium from East to west in the ninth century was employed by later papal supporters as an example to demonstrate the debt owed by the western emperors to the papacy. Twelfth and thirteenth century canonists utilized the writings of many ninth century authors like Alcuin, who maintained that both secular and ecclesiastical powers were within the church. 25

The second formula to be derived from the rise of Charlemagne was in the area of election practices. The first western medieval emperor, Charlemagne, was simply given the assent of the primores and optimates. ${ }^{26}$ The idea of an election never entered the picture, because Charlemagne's right to rule was held de facto.

Europe witnessed a diminution of centralized power following the death of Charlemagne in 814 . There were many losers in the fighting that followed, but the lesser lords and the Roman pontiff emerged from the vacuum the winners. Subsequently, emperors were subject to increasing demands for justice and right rule. What ensued was a "give and take" dynamic, one which demanded repeated declarations of rights possessed and duties owed. This point is illustrated

\footnotetext{
${ }^{25}$ Carlyle, 147 .

${ }^{26}$ Ibid. , 241.
} 
in a rebuttal by Charles the Bald to those who wished to depose him for ineffective leadership in the 870 's. First, he pointed out his right of succession through hereditary prerogative. Secondly, he argued that he was elected by bishops and other devout men, and anointed by the bishop, Wenilo of orleans. He could be deposed only by those who had elected him and none other. ${ }^{27}$

In the power struggle between pope and emperor, the ninth and tenth centuries provide a watershed of seminal thought. Attempts were made to draw up rules for this contest between competing factions. First, it must be recognized that the competition took place on an ideological plane, for the emperor had the physical might to do whatever he considered expedient. Theoretical justifications were oftentimes secondary to the reality of the situation, as with the apparent obedience of Pope Leo III and Leo IV to the emperors charlemagne and Lewis II in several Church matters. The emperor held sway over the church in three main areas in the ninth century. He protected the church. He still had the right to call synods. And lastly, he could appoint bishops.

Predictably, the early church Fathers were studied for advice on the matters of auctoritas and maiestas. Often, those who supported imperial claims of supremacy based their religious arguments on the teachings of Pope Gregory the

${ }^{27}$ Ibid., 252. 
Great. Those who supported the authority of the church and Pope, used the writings of Pope Gelasius I and the example of Pope Zacharias as their primary proofs. Jonas of orleans wrote in the ninth century that, while the emperor is subject to priest in ecclesiastical matters, and the priest is subject to the emperor in secular matters, the priest has some obligation to see that the secular world reflects God's justice. ${ }^{28}$ Hincmar of Rheims, writing at the same time, noted that the pondus sacerdotum put forward by Pope Gelasius I, was much greater than that of the emperor. Thus, the priest is forced by conviction occasionally to involve himself in matters of the state. ${ }^{29}$ The issue of the relative power of the church and state was not a major one to western society in the ninth century. The common view probably accepted the duality of leadership, and recognized the supremacy of each power in its respective realm. ${ }^{30}$

Another next example which serves to illustrate the evolution of the papal/imperial power struggle occurred in the eleventh century with the investiture contest. This is a period when an increasingly secularized Church began to assert itself forcefully in the political arena. The idea of papal monarchy was first manifested in this time also.

\footnotetext{
${ }^{28}$ Ibid. , 256.

${ }^{29}$ Ibid.

${ }^{30}$ Ibid. , 287.
} 
This evolution found expression in the bull Dictatus Papae, promulgated by Pope Gregory VII, styled Hildebrand, against the practice of lay investiture. This bull proclaimed that "[ the Pope himself] may be judged by no one", and "that it is permitted to [the Pope] to depose an Emperor." The pope may punish the emperor if he is disobedient or an imperial proclamation "not in accord with the Roman church is not held to be catholic."31

The investiture contest pitted the proverbial immovable object against the irresistible force. The reactions of Henry IV in 1076 demonstrate clearly the ambiguity of rights which existed between church and state. Henry IV would not recognize the pope's authority in making the claims presented in Dictatus Papae. The historic meeting at Canossa in 1077, which briefly reconciled the excommunicated Henry IV and Gregory VII and gave the papacy a momentary upper hand, proved in the final analysis an impasse for both parties. Henry returned to Germany to face his dissident princes. Gregory lost the support of the princes facing Henry because of his forgiving gestures. What one finds after the reign of Gregory VII is a papacy which is less afraid to confront the emperor over secular matters. In addition, the issue of papal authority takes on wider implications.

The papacy had one distinct advantage over the emperor 381 .

${ }^{31}$ Ewart Lewis, Medieval Political Ideas (London, 1954), 
in the twelfth and thirteenth centuries. A pope could boast of having the best minds in Europe at his disposal. Having a virtual monopoly on universities had its advantages. From this font sprung many of the greatest intellects of the Middle Ages. These men tended to side with the pope in matters concerning the distribution of power, and they always recognized that the greater goal was spiritual. The twelfth century is rife with attempts by the papacy to regularize and legitimate itself. The strongest and most influential document on papal power from this period was the Concord of Discordant Canons, commonly called the Decretum, written by Gratian, a Bolognese monk around 1188. Its purpose was to systematize many of the divergent doctrines and canons of the twelfth century church. For our purposes, it dealt extensively with the powers of the papacy. Gratian's canonistic glosses were juridical in nature. They were designed to support the pope's claim that he held the court of last resort. Lastly, the Decretum maintained that the judgements of the pope were superior to those of worldly judges. 32

Mid-twelfth and the thirteenth centuries students who examined the validity and limits of Gratian's concord were called Decretists. One of the most learned scholars of the period and a subscriber of Gratian's decrees was orlando Bandinelli, who later became Pope Alexander III. His sharp

${ }^{32}$ Carlyle, vol. 2, 216 . 
legal mind pushed to the limit the idea of papal auctoritas, as is evidenced by his struggle as pope with the Holy Roman Emperor, Frederick I. Alexander III's dogged determination and refusal to submit to Frederick prevented the papacy from becoming merely a pawn to a dominant emperor. ${ }^{33}$

Extreme imperial claims of supreme potestas provoked an equally excessive tendency for papal claims in the same direction. A noted twelfth century decretist in this vein was Ricardus Anglicus. He employed a radical rendering of Matthew 16:18, giving Peter the keys to both Heaven and earth. Anglicus asserted that universal juridical and political dominion were attributes of the papacy. This hypothesis maintained that the pope, as vicar of Christ, has power over everything. An emperor's power is secondary in every respect. As J. A. Watt points out, "These are extremist arguments and no twelfth century decretist was prepared to press the canons so hard." 34

The issue of papal power involved one of the greatest minds of the Middle Ages. Bernard of Clairvaux argued for the Church's right to both swords. Unlike Ricardus Anglicus, however, he was more in tune with the secular realities. Bernard believed that the Church possessed, but

${ }^{33}$ Walter Ullmann, The Papacy and Political Ideas in the Middle Ages (London: Variorum Reprints, 1976; repr., Rome: Miscellanea Historiae Pontificiae 18, 1954): 124-25.

${ }^{34} \mathrm{J.A}$, Watt, "Spiritual and Temporal Powers," in The Cambridge History of Medieval Thought ed. J.H. Burns (New York: Cambridge University Press, 1988), 377. 
should not use the temporal sword.

Both swords, spiritual and material then, belong to the church; the one exercised on behalf of the church, the other by the church: the one by the hand of the priest, the other by the hand of the soldier, but clearly at the bidding of the priest (ad nutum sacerdotis) and the order of the emperor.

In other passages he implies that any ruler who does not rule justly may find himself censured by God, and theoretically by extension, by the vicar of christ, the pope. ${ }^{36}$ The implications of st. Bernard's beliefs on the proper ordering of Christendom were extensive. It is not surprising, then, that later canonists often adopted and altered his ideas in ways st. Bernard would scarcely have recognized.

The nature of the argument changed somewhat in the following century. The thirteenth century was marked by a increasing rediscovery of antiquity and the classics. The works of Aristotle became a central field of focus. Equally important was the rebirth of Roman law. Both rediscoveries brought new ways of seeing the papal/imperial contest. subsequently, it was not until the thirteenth century that the "twelfth century Renaissance" experienced full flower. The metaphor of the two swords received a great deal of consideration in the thirteenth century. Predictably, church scholars led the way in this discussion, but

\footnotetext{
${ }^{35}$ Ibid., 373.

${ }^{36}$ Ibid. , $373-374$.
} 
supporters of imperial autonomy, buttressed by the rebirth of Roman law, wrote cogently on the issue also. One such writer was the famous canonist from the school of Bologna named Huguccio. He believed that the emperor possessed the secular sword separately. Huguccio wrote that the emperor held the sword and imperial dignity through election by the people. He also stated that there was an emperor before there was a pope, thus a priori, the emperor owed only a limited amount of his prerogative to the pope. He stressed that there was a dualism of power, condoned by God. ${ }^{37}$

Out of the thirteenth century milieu arose an increase in the number of extreme positions taken on papal power. Aegidius Romanus offered a comprehensive, often repetitive defense of papal auctoritas. Romanus stated unequivocally, that the Summus Pontifex holds both swords from God, and it is the high priest who allows the use of the temporal sword by the emperor. ${ }^{38}$ The power of the pope is not to be ignored. The pope holds legislative eminence also. He judges all and is judged by none. ${ }^{39}$ He is able to institute earthly power, and if it is bad, he is able to judge the difference. He stated that no power is valid if it is not approved by the Church: "Quoniam in omnibus temporalibus ecclesia habet dominium universale, fideles

${ }^{37}$ U1 l mann, 142 .

${ }^{38}$ Aegidius Romanus, De Ecclesiastica Potestate ed. R. Scholz (Weimar, 1929), 1.

${ }^{39}$ Ibid. , 2 . 
autem de iure et cum iusticia dominium particulare habere possunt." and "Quod infideles omni possessione et dominio et potestate qualibet sunt privati."40 Romanus believed that the Church was a repository for power. "Quod in ecclesia est tanta potestatis plenitudo, quod eius posse est sine pondere, numero et mensura." ${ }^{41}$ This thirteenth century exercise in political propaganda was quite persuasive. It proliferated at a time when secular rulers were either agreeable to it, too weak to oppose it, or otherwise too occupied.

Arguably the greatest mind of the thirteenth century was Thomas Aquinas. The influence of Aristotle's Politics on Aquinas' De Regimine Principum (Concerning the Rule of Princes) and Summa Theologicae is inescapable. Aquinas' arguments were theologically polarized, especially when potestas papae et ecclesiae entered into the discussion. Thomas Aquinas offered one of the most comprehensive treatments of the problem of ecclesiastical auctoritas. His arguments on papal authority are more theoretical in nature, reflecting less the struggle between the popes and emperors of his time, and more the abstract relationship between prince and priest. Aquinas fully recognized the importance

40"Although the Church has universal dominion over all temporal things, the faithful nevertheless can legally and justly have particular dominion . . . . Non believers are unworthy of any form of possession, dominion or power." Ibid.

41 Plenitude of power in the church is so great that what she can do is without limit, number, and measure. Ibid., 3 . 
of secular leadership, and was willing to grant it freedom in its sphere, so long as it ruled justly. In the end, the prince's freedom is shackled by Aquinas's insistence that heaven must be the greatest end, and the pope held the key to this end, thus the pope was superior, and by necessity, his power was universal. 12

Through skillful employment of scripture, the dicta of the Church fathers, and Aristotle, Aquinas was able to delineate and define, to a greater degree than had previously been established, the appropriate roles of $\mathrm{king}$ and prelate. He proceeded by stating that in everything, there is an end, the intended end of man is the company of God. Therefore, the highest good a ruler, either secular or ecclesiastical, must be to ensure and facilitate this end through virtuous leadership. Aquinas rebuked the idea that the pope's power did not extend beyond spiritual authority. He made an analogy which compared the spiritual and temporal to the soul and the body: "in the individual man, the soul rules the body. . . Therefore in every multitude, there must be some governing power." 43

Aquinas belonged to a century in which conflict between pope and emperor occurred frequently. In the thirteenth century, the dimensions of the struggle were

${ }^{12} \mathrm{st}$. Thomas Aquinas, Summa Theologicae, in Basic Writings of Saint Thomas Aquinas ed. A.C. Pegis (New York: Random House, 1945), Pt. I-II, Ques. 17, Art. 9, Reply obj. 3 .

${ }^{43}$ Tierney, 169. 
stretched to their furthest extent by the contest between Emperor Frederick II and Pope Innocent III. The strong personality of Frederick II was more than counter-balanced by that of Pope Innocent III. The papacy reached its political zenith in this period, but the legacy of this expansion was a continual overestimation by the papacy of its real power.

The right of the pope to approve and to crown the emperor was solidified by Innocent III. In so doing however, he set a unfortunate precedent by helping the covetous Guelf candidate, otto get elected emperor. Once Innocent II realized that otto had no desire for the role of custodial emperor, nor cared about respecting papal rights, he reversed his favor and turned to Frederick II, the youngest son of Emperor Henry VI. While this event demonstrated the power of the papacy to approve a candidate for emperor, it also showed the degree to which human folly entered the process. Frederick II, after consolidating his power and defeating otto, proved himself to be a more implacable foe than otto. A lesser pope might have blinked in the face of confrontation with Frederick II, but Innocent II was equal to the task and able to defend his ideas on papal auctoritas.

The problems between the papacy and Frederick II in the thirteenth century did not develope fully until the pontificate of Gregory IX. Frederick II's insolence toward the papacy was not tolerated by the volatile Gregory IX, as 
it had been under his immediate predecessor, Honorius III. From the reign of Innocent III to that of Innocent IV, we see a slow, but steady rise toward the idea of papal monarchy. The innovation of these popes was manifested by their ability to actualize the secular sovereignty that they had hitherto claimed only theoretically. With the downfall of Emperor Frederick II, and the subsequent subjugation of the imperial office, papal auctoritas reached the full expansion of its meaning.

The amazing growth of papal power in the thirteenth century was made possible by two contributing factors. In large part, the thirteenth century was marked by rulers benevolent toward the Church. The legacy of st. Louis IX of France and the weaker, but no less religious, Henry III of England, was an abiding magnanimity toward the Church and papacy. The second and more immediate factor in the emergence of the papacy as a secular power was the lack of centralized support for a single emperor. The fourteenth century presents us with a papacy trying to assert similar demands on stronger monarchs, but to less avail.

Invigorated by more centralized leadership and the primal seeds of nationalism, France and England had more leeway in dealing with the papacy. The Holy Roman Empire was not afforded the same luxury. The German electors and other Teutonic nobility were granted so much autonomy by imperial claimants in the thirteenth century that little power was available to the emperor when the next struggle 
with the papacy arose.

At the turn of the fourteenth century, the emperor had come to take on the role of defensor Ecclesiae. As we have seen, the role of the emperor in western Christendom had evolved from a position of secular, autonomous leadership, to one of "protector" and dependent of the Church. After the power struggles between Church and state in the thirteenth century, the Church had gained the stronger position in the relationship. It was now agreed that an emperor was not fully an emperor until he had received papal approbation in Rome. Innocent III's decretal Per Venerabilem was responsible in large measure for this and became a blueprint for future papal/imperial interaction. ${ }^{44}$ The theory of dominium comes into play with the idea of defensor Ecclesiae. Dominium is "the preordained relation of superior to inferior." 45 Contingent upon this theory is the idea of proprietas. This refers to the relationship between a person and a thing. God has dominium and proprietas over the universe and he has meted them out according to favor. Possession or control over a thing does not necessarily grant true authority over it, if it is not exercised "of right." In the divine program, the pope is the secular as well as ecclesiastical leader. The pope, who is universal leader "of right," employs the emperor to

${ }^{44}$ Carlyle, vol. 5, 230-31.

${ }^{45}$ McIl wain, 250. 
perform the directly secular missions so as to leave the church unblemished. ${ }^{46}$ Clement VI was acting out of this understanding of defensor Ecclesiae, when he began to resolve the problems with Louis IV of Bavaria.

If the thirteenth century represents the zenith of the papacy, then the fourteenth century represents its nadir. Alexander Flick demonstrated how the fourteenth century was one of ecclesiastical decay, and the beginning of the fall of the Medieval church. He points to several factors which precipitated the decline. One was the formation and realization of the idea of nation/state. Another reason was the deterioration of feudal and hierarchical order. Flick maintained that the church lost sight of the needs of the masses. It had grown rich while most of Christendom was struggling at a subsistence level. Yet another reason for a weakening of Church authority, in secular matters, was the rise of an educated lay society, which could combat the canonist on a more equal footing. Finally, the commitment to a single universal Christian society, led by the Pontiff and governed by the emperor, became unrealistic. ${ }^{47}$

The papacy claimed full authority over all kings and emperors. The political reality of strong monarchies in the fourteenth century confuted and challenged this assertion repeatedly. The greatest challenge to papal auctoritas in

${ }^{16}$ Ibid., $249-50$.

17 Alexander Flick, The Decline of the Medieval Papacy vol. 1 (New York, 1930), 54-56. 
the Middle Ages, short of the Reformation, was the contest between Boniface VIII and Philip IV of France. France enjoyed a special relationship with the papacy; it had been long established that the French monarch had special dispensation to direct the ecclesia gallicana. The bull Clericis Laicos, issued in 1296, ruled that it was unlawful for laymen to tax the clergy. It threatened punishment with the most powerful weapons available to the pope. Interdiction and excommunication threatened anyone who disobeyed the Bull. Boniface VIII's challenge was extended before the implications and consequences were fully considered. Both England and France responded by asserting the autonomy of their rulers. Philip IV placed a ban on all money leaving France. When Boniface VIII realized the total ramifications of his act, he issued several bulls which were intended to placate the animosity created by clericis Laicos.

A brief period of detente ensued. Philip IV, perceiving the papacy to be shaken, and France needing money to prepare for the imminent war against England, began to pressure the clergy for more money. Boniface VIII responded to these affronts by issuing the bulls Ausculti Fili and Unam Sanctam, which reasserted the supremacy of the pope's authority. Philip IV employed brutal tactics to quiet Boniface with force. Boniface was beaten and, shortly thereafter, died in humiliation.

Philip IV's actions were without precedent. The 
height of the thirteenth century papal monarchy was brought to a low. Possibly even more humiliating was the fact that by the end of the thirteenth century, the pope had little real authority in his own patrimony of Rome. Familial infighting had reduced Rome to a lawless state. It became evident, to many in Christendom, that papal assertions of universal authority were theoretical only.

The history of the pontiff and the French monarchy is not the focus of this research, but the feud between Boniface and Philip demonstrates clearly that the rules of the conflict between church and state had changed. The biggest threat to the papacy was not the Holy Roman Emperor; it was the French monarch. The papacy now needed a suppliant emperor to counter-balance the weight of French influence. 
CHAPTER I I

POPE CLEMENT VI AND THE GERMAN EMPERORS:

PAPAL AUTHORITY VERSUS IMPERIAL RIGHTS

The period between the death of Emperor Henry VII in 1313 up to the election of Emperor Charles IV in 1346 is a watershed for canonistic debate and papal/imperial polemics. The imperial problem, which began in the reign of Pope John XXII and extended into the reign of Pope clement VI, demonstrates how the rules that governed the old relationship between pope and emperor evolved to fit the turbulent fourteenth century situation. With the precepts of earlier centuries still fresh in the mind, let us now consider this last great papal struggle to attain auctoritas.

At the heart of the problem was the election of Lewis IV of Bavaria. When Emperor Henry VII died in 1313, fourteen months elapsed before another emperor was elected. similarly, when Pope clement $V$ died, there was a two year gap between pontiffs. There was a window of time from April 1314 to November 1314 when Europe had neither an emperor nor a pope. This regnal anomaly greatly exacerbated the divisions of the times.

Two contestants vied for the imperial office, Lewis, Duke of Bavaria, and the Hapsburg candidate Frederick, Duke of Austria. To add to the confusion, when the imperial electors did finally meet, two of the seven electorates were 
being contested. The electorate of Saxony was split between the Duke of Lauenburg and the Duke of Wittenberg. The electorate of Bohemia was contested by John, Duke of Luxemburg and Henry, Duke of Carinthia. Lewis garnered the support of the Margrave of Brandenburg, Baldwin, Archbishop of Trier, and Peter, Archbishop of Mainz, with the added support of two contested electors, the Duke of Lauenburg, and John of Bohemia. Frederick received the support of the Archbishop of Cologne and the Elector Palatine, adding the support of the feuding electors, Henry of Carinthia and Rudolf, the Duke of Wittenburg. ${ }^{1}$ since the imperial election was based on plurality, only four votes were necessary to be elected. Lewis of Bavaria amassed five votes; Frederick of Austria received four. Both contestants claimed victory.

The dispute may have been mediated more easily had there been a seated pope, but as was stated previously, the imperial election occurred between the pontificates of Pope Clement $\mathrm{V}$ and John XXII. Frederick was crowned first in Bonn by the Archbishop of Cologne. Then, Lewis followed by being crowned at Aix-la-Chapelle, performed by the Archbishop of Mainz. The elected emperors repudiated each other's claim as being invalid. The dispute raged on for eight years. Lewis and Frederick were both popular to their

William stubbs, Germany in the Later Middle Ages, $1200-$ 1500 ed. Arthur Hassall (New York: Howard Fertig, 1969), 10001 . 
subjects, but Lewis had the stronger force. On 28 September, 1322, Frederick was captured at the battle of Muhldorf and imprisoned. Lewis claimed himself sole ruler of the empire and sought papal support. John XXII replied that he needed time to study the issue, and only then would he mediate the dispute. This infuriated Lewis IV, and from that moment, the gap between the emperor and the papacy widened.

German historiographers paint Lewis of Bavaria as a pious man, loved by his subjects and an able ruler. He was not however a great legal mind. Lewis was forced to chose the option of promoting his imperial claim over servitude to an insecure papacy. He proceeded with his plans to be crowned in Rome, regardless of papal opposition.

Lewis IV was shrewd enough to enlist the help of the dissident Franciscans. This sect of Franciscans had previously fallen out of favor with Pope John XXII over the doctrine of apostolic poverty. The dissident Franciscans favored the extreme, ascetic position which seemed to threaten the correctness of the church amassing secular wealth. Threatened with imprisonment by John XXII, Michael of Cesena, Minister General of the Franciscans and William of Ockham fled to Lewis IV's court. They joined Marsilius of Padua and John of Jandun, who had been at Lewis IV's court since escaping the papal grasp in 1326. Lewis IV recognized the advantage of retaining some of the most innovative thinkers of his time. He put them to work by 
having them write tracts on imperium and potestas.

The most radical statements on imperium and potestas were registered by Marsilius of Padua. In his work Defensor Pacis, he described the Church as merely a department of state. He meant the whole body of the Church, not the clergy only. The people who make up the universitas Eidelium are the same people who make up the universitas civium. This unification is best understood if Aristotle's hermeneutics of accidence are applied. "Thus, while the fideles and cives are the same in person, they differ in the attributes whereby they have these respective designations; - . they are the same in number, but differ in essence."2 One of Marsilius's strongest arguments for imperial eminence builds on his perceptions of the evolution of papal power. There are continual references to the early church and the growth of the idea of the primacy of Rome over other equally important Christian cities in the Mediterranean basin. He demonstrated through Biblical reference that the apostles were commanded by Jesus to leave temporal affairs to temporal rulers and to concern themselves with the act of saving souls. 3 Marsilius of Padua's caesaro-papist notions were generally wasted on the more reverent Lewis of Bavaria, who was not willing to proceed as far as Marsilius would have him go.

'Alan Gewirth, Marsilius of Padua, The Defender of Peace vol. 1 (New York: Columbia University Press, 1956), 293-94. ${ }^{3}$ Matt. $22: 21$. 
Marsilius of Padua's major contribution to the debate over imperium versus auctoritas was that he completely discounted the viability of the hierocratic theory. He realized that as the debate was currently conducted, it was weighted against the emperor with its heavy emphasis on theological and hypothetical argumentation. He grounded his proofs on classical texts and Roman law. The Bible was employed only as a secondary source. Few writers of the time were prepared to take such radical steps. One need only compare Dante's earlier pro-imperial Monarchia with Marsilius' Defensor Pacis, written only twenty-five years later, to recognize the radical departure of Marsilius from the standard modes of argumentation.

Another ally of Lewis IV's was William of Ockham. He was quite comfortable in arguing for imperial power within the confines of theological debate. The early career of Ockham was distinguished by his work on Peter Lombard's Sentences and his devotion to empiricism. It was not until he came to Avignon to be questioned about many of his theological writings that he took any interest in political matters.

Ockham arrived at Avignon in 1324. In 1328, he fled from the papal court with Michael of Cesena, the General of the Franciscan Order. It was at Cesena's request that Ockham began writing on the polemical matter of Franciscan poverty. In a nutshell, an uproar was created in many circles when Pope John XXII denied the essence of necessary 
poverty, because of the implications it had on the ecclesia universalis. Pope John XXII believed that the Church had a right to own property and that Holy scripture backed him on this. John's own theories on Apostolic poverty were contradictory to some of the decrees issued by his predecessors, notably, Pope Honorius III and Nicholas III, which seemed to support the spiritual Franciscan viewpoint. John's renunciation of his predecessors decrees, occasioned much debate over the infallibility of the pope.

The doctrine of infallibility was probably first formulated by Peter John Olivi around 1280. He maintained that papal pronouncements on issues of faith were infallible and binding on all Christendom. For the papacy, the positive side of this theory was that christendom was bound to hold to those papal pronouncements which were firmly buttressed by scripture as if they were straight from God. The down-side to this theory lies in its interpretation and its implications: it can limit the power of succeeding popes. If one pope makes an ex cathedra decree, it is passed down and is held infallible; the next pope can not come along and simply change it. 1

The Franciscans were in favor of the theory of infallibility for obvious reasons. If John XXII made

'James Heft, S.M., John XXII and Papal Teaching Authority Text and studies in Religion, vol. 27 (Lewiston, N.Y.: The Edwin Mellen Press, 1986), 169-70. Brian Tierney, Origins of Papal Infallibility: 1150-1350 (Leiden, Netherlands: E. J. Bril1, 1972), 14-15. 
pronouncements against Apostolic poverty, then he denied Pope Nicholas III's declaration which favored Apostolic poverty. This was tantamount to denying the logic of infallibility. Displaying questionable theological astuteness, John XXII replied that God had granted the right to hold property before the Fall and that scripture gives examples of the Apostles owning property, therefore he was exercising his sovereignty in issuing his Quia Quorundam Mentes, which appeared to revoke Nicholas III's pronouncements on Apostolic poverty. ${ }^{5}$

clement VI, on the other hand, believed that he could not err in matters of the Holy Church because God would not allow him it. He even refers to himself as "vicar of Him who could not and did not wish to err." 6 clement supported John XXII's right to change the rules by calling to mind the passage from Esther 15:9, "For the future we will take care to render out a kingdom quiet and peaceable for all men, by changing our methods and always judging what comes before our eyes with more equitable consideration." This was shaky ground to tread upon, owing to the weakening effect it had on papal authority. It is not with surprise that we see clement VI avoiding the subject, as John XXII tried to do,

${ }^{5}$ Brian Tierney, origins of Papal Infallibility: 1150-1350. (Leiden, Netherlands: E. J. Brill, 1972), 18990.

'Diana Wood, Clement VI, The Pontificate and Ideas of an Avignon Pope (Cambridge: Cambridge University Press, 1989), 36 . 
as often as possible; and that the only time that clement broached the matter was in relation to canonization.? Clement VI avoided much confrontation by making a distinction between infallibility on matters of faith and the pontiffs sovereign right to make juridical decisions. Clement dealt with the dissident Franciscans in three ways, that is, he avoided any confrontation over infallibility, he regularly asserted his vicarage, and he tried to avoid making proclamations which were not biblically reinforced. Infallibility becomes questionable only when it lacks sound scriptural basis. Pope clement VI was prudent enough not to allow himself to be drawn too deeply into theological matters of infallibility.

When the Franciscan debate heated to a boil, william of Ockham fled to Avignon to the court of Lewis of Bavaria. At the behest of Lewis, he looked into the matter of Lewis's claim to the imperial throne. It was under this umbrella that Ockham began to explore the dynamics of the relationship between church and state, and furthermore, to define more narrowly the powers and limits implicit in the alliance.

The balance of Ockham's political thought on the matter can be garnered from four of his works, the Dialogus, the Breviloquium de potestate Papae, his octo quaestiones de potestate Papae, and An Princeps pro suo succursu, scilicet

I Ibid., 38. 
quere, possit recipere bona ecclesiarum, etiam invito Papa.

of major concern to Ockham was the widely held view, at least in the intellectual circles of the fourteenth century, that the pope's power was absolute. Many held that the only impediment to the pope's power rested on the degree of divine support and its continuity with natural law. ${ }^{8}$ Ockham believed otherwise.

In the name of liberty of the Holy Gospel he protested against such a usurpation of absolute power. For him, the new law of the Holy Gospel is a law of free men in christ, and by its very nature it does not admit of any servitude which even equals, let alone surpaspes, the yoke imposed upon the Jews by the old Law.

Rather, the pope is submissive to the needs of

Christendom. Ockham did not totally discount potestas papae. No one could deny that the pope had great power, which was endorsed by Scripture. Ockham was not so much concerned with the source of his power, but rather its limits. In his Dialogus, Ockham conceded that the pope's power was very great, and that he was not beholding to any man for it, but it was not absolute. He wrote that the pope's power was attained from God through Peter, and that the pope possessed the same power that Peter held. The pope was said to have dominion over spiritual matters, including over forces that are indispensable to the proper maintenance

${ }^{8}$ Philotheus Boehner, collected Articles on Ockham, ed. E.M. Buytaert (St. Bonaventure, N.Y.: Franciscan Institute, $1958), 448$.

'Ibid. , 449. 
of the Church. Ockham did not believe that supererogation was a papal attribute.

Ockham wrote that the pope's judicial powers were extensive in two areas. The first area was in the remission of sin. The pope has the right to enforce his judicial decisions, but only as they apply to ecclesiastical misconduct. In secular matters, Ockham believed that the pope must let the laity decide. While the pope should not judge a civil case, he can add to the civil penalty. A pope's authority can be revoked if he is remiss in his duties to the point of compromising the public safety. Ockham believed that the pope had the right to demand those material commodities which help facilitate the proper running of the Church. The two barometers for Ockham, which could be applied by any Christian to gauge papal competency were the measures of Holy scripture and right reason. He reckoned that any act which violated either of these two requirements could not be just actions. Echoing Dante and st. Bernard, Ockham stressed the pope's ministerium role over his role of dominum. ${ }^{10}$

Concerning the right to hold property and the closer perfection of poverty, Ockham wrote, "the right to acquire private property. . . is not a sign of perfection. For in perfect man, such as Adam and Eve were in their original innocence, there is no avarice nor any greediness to acquire

${ }^{10}$ Ibid. , 454. 
or to use any temporal thing against the dictates of right reasoning."ll The right to have property is a God given right, and is not wrong if it is a remedy. Since property is given by God, there is no need for an intercessor (1ike the pope), to act with any jurisdiction. Government is a natural extension. Unlike the Augustinian view, Ockham held that government was "not an effect of sin, but is only occasioned by sin."12 Therefore secular government is outside the jurisdiction of the Church. Two outgrowths of this formulation are the right of a man sound in mind and not harmful to society to renounce his rights to property and assume a vow of poverty, just as a man has the right to rule over property divinely conferred.

In relation to the potestas of the papacy, Ockham wrote that power can be divinely conferred in three different senses. The power that Moses received was direct and without agent. In a second sense, the power that the pope wields is given by God to all the successors of Peter, but it is not totally independent owing to the fact that the pope is elected. The third route of divine power comes from God to men who have power ipso facto, that is, an office or dominion by concession, donation, or resignation. ${ }^{13}$ The third sense is the root of secular power. As proof that
H Ibid., 455 .
${ }^{12}$ Ibid. , 457 .
${ }^{13}$ I bid. , 459. 
this arrangement is divinely legitimated, Ockham relates how even in non-Christian kingdoms, rulers have dominion. Borrowing from the classical Roman model, Ockham believed that divine approbation resides with the people, who then confer it on the ruler. After divine power has been delegated, the ruler is owing to no one but God. It cannot be expropriated, but by just cause. 14

Ockham believed that the Roman Empire's legitimacy rested on a firm foundation of consent, force and divine support. Ockham reflected on the Classical Empire, and the precedent it set for the Holy Roman Empire. Christ recognized the Roman Empire as legitimate, as did the Apostles. Consequently, by extension the Holy Roman Empire was autonomous and righteous.

As Boehmer points out, Ockham never wrote specifically on the power relationship between the Church and state. It was understood that they both existed for the same reason, the good of the common weal. The occasion for both was the same, original sin. ${ }^{15}$ The papacy can not intrude in secular affairs without scriptural support; if it does, it sins.

Whether out of conviction or compunction, Ockham denied the pope much latitude in secular affairs. He made several points which make this clear. The pope, he wrote,

\footnotetext{
${ }^{14}$ Ibid. , 460.

${ }^{15}$ Ibid. , 465.
} 
cannot depose (deferre) a temporal ruler, because he has no jurisdiction in temporal matters; the electors are the only ones with any rights in the matter. In the example of the "two swords," Ockham stated that the pope can "exhort" the temporal ruler to use the sword if the latter is slack in his duties, but he cannot command him to do so. He inserted an escape clause by saying that in cases where "the highest utility and necessity is in question, the pope himself may unsheathe the sword justly, manfully, and powerfully."16 Ockham treated the issue of the emperor's authority over the pope less thoroughly. The emperor has the right and the duty to interfere in ecclesiastical matters if the pope is jeopardizing the common good or is heretical. This justification was arrived at by Ockham to defend Lewis IV's right to render marriages invalid on the civil side, as long as it did not go against the sacramental side.

Ockham must be recognized as less radical in his thought than Marsilius of Padua. Ockham was forced into the political sphere by what he interpreted as poor, if not heretical, leadership by the Avignonese papacy. Ockham's attacks on the papacy, unlike Marsilius's were intended to be corrective, not destructive.

Lewis IV used Ockham and the Franciscan dilemma to a large degree for his own end. It is questionable whether he had any strong feeling for the plight of the dissident

${ }^{16}$ Ibid., 467. 
Franciscans. He was operating on the assumption that "my enemy's enemy is my friend." Regardless of motives, the fact remains, when Lewis went to Rome to be crowned emperor, the Franciscans provided an invaluable service.

Since it was evident that John XXII was not going to bestow the imperial dignity on him, Lewis attempted to outflank the papacy by creating a new pope with the Spiritual Franciscans help. Lewis IV chose a Franciscan named Pietro Rainalducci of Corvaro to style himself as Pope Nicholas $V$. The charade lasted long enough for Lewis to be crowned, but Italy was too hostile an environment to remain there for long. The stakes proved in the long run to be too high. In December 1329, Lewis left Italy after daily struggles with Ghibellines and various Italian cities and returned to Germany. Nicholas $V$ was left in Rome with no provisions for holding out against the forces hostile to Lewis and himself. He lasted until $25 \mathrm{July}, 1330$, when he was captured, and later turned over to John XXII. He was basically forgiven by John XXII for his rebellion and spent the last years of life in relatively comfortable imprisonment.

Probably no writer better portrayed the real political conditions of the mid-fourteenth century than Baldus de Ubaldis. He posited that the emperor and the pope both enjoy universal sovereignty. Further, this sovereignty is granted directly by God. Ubaldis stated that each office has its particular sphere of influence, where its rights are 
inviolable. There are two recurring themes to Ubaldis's arguments. First, that a feudal relationship exists between pope and emperor, and secondly, that Roman law was central to the early conceptions of the papal/imperial relationship. A study of his writings reveals that Ubladis's heart was with the pope, but his head favored the emperor.

Owing to the fact that the pope crowned the emperor, argued Ubaldis, a feudal relationship between lord and vassal theoretically existed. He hypothesized that this feudal relationship had reciprocal implications because of the Donation of Constantine. In this forged document, Constantine was said to bequeath the western half of the empire to the pope. Since it was the emperor who originally had the power to confer the gift of sovereignty, his descendants had rights as a result.

In cases where the pope acts irrationally and without iusta causa, the liege has the right to resist. One such right, which Lewis IV argued for, was the right and duty of the emperor to resist the wishes of the papacy when it tilts toward tyranny. Ubaldis stated,

And there is another reason: the church has a reciprocal obligation to its vassal, and cannot harm him as regards his empire. Indeed the pope shows himself unsuited to his power if he does not render such justice to the emperor who swore fealty to him ..... And the emperor can defend himself with his army.

Ubaldis did not believe that the pope was a junior

${ }^{17}$ Joseph Canning, The Political Thought of Baldus de Ubaldis (Cambridge: Cambridge University Press, 1987), 40. 
partner in the universal arrangement. The pope holds his universal sovereignty separate from the emperor. In defining the power of the pope, he wrote,

The [pope] is not only a bishop, but the chief of bishops and of others whom the intellect can imagine. To him has been given the full power of the keys and that highest and unrestricted power freed from all constraints of canon law and from every limited rule except the law of the gospels and the apostles.

In relation to the election of the emperor, Ubaldis

followed the formula put forward by Pope Innocent III,

The princes should acknowledge, and indeed they do acknowledge, that the right and authority to examine the person elected as king, who is to be promoted to the imperial dignity, belong to us who anoint, consecrate and crown him; for it is regularly and generally observed that the examination of a person pertains to the one to whom the laying-on of hands belongs.

Once the election has been promulgated and approbation given, the pope is limited in his authority over the emperor.

In addition to the feudal rights granted to any vassal, the emperor also possessed the theoretical status of patronus. It was the emperor's duty as patronus to ensure that he use his power wisely. As patronus, his role was purely that of an officer, whose job it was to secure the common good, the utilitas publica. ${ }^{20}$

Important to Ubaldis was the concept of lex reqia,

${ }^{18}$ Ibid. , 31 .

${ }^{19}$ Tierney, 133.

${ }^{20}$ Ibid. , 106 . 
from which the emperor's power is derived. The rule of law is based on the acclaim of the people. Ubaldis argued that lex regia also functions under the advocacy of God. Since imperial power is direct from God, with the populace acting only as agent, Ubaldis held that imperial sovereignty was independent of any man or office. Furthermore, the emperor's juridical powers were direct from God. Ubaldis reasoned that if the Holy Roman Emperor derives his power from the precedent set by the first Roman emperors, and Jesus recognized the sovereignty of these early emperors, it holds that Jesus would also accept the sovereignty of their successors. As Ubaldis stated, "And again that supreme dignity was instituted by God, and cannot therefore be suppressed by man."21 While Ubaldis's arguments were not especially creative, they seem to reflect most accurately the common perceptions of the day.

The struggle between the papacy and the emperor was overshadowed during the decade of the 1330's as England and France postured and prepared for war. Lewis IV's competitor to the imperial throne, Frederick of Austria, had died by this time. Active papal intervention by John XXII with the imperial electors had created dissent and was a constant nuisance to Lewis IV. In an attempt to bolster his influence, Lewis joined forces with Edward III and threatened to offer an eastern front against the French. In

${ }^{21}$ Ibid. , 27. 
1328, Lewis concluded a pact with Edward III, which granted Edward the vicarage of the Empire. Under the advice of Philip VI, Pope Benedict XII offered opportunities to Lewis for absolution in hopes of drawing Lewis away from Edward III. Burdened by the weight of John XXII's previous excommunication and interdiction, Lewis VI appealed to Benedict XII for forgiveness and approbation of his imperial rights. Just as papal favor seemed imminent, Philip VI of France stepped in and dashed all plans. ${ }^{22}$ This act made evident what had previously been presumed: the papacy was, at the least, partially controlled by the French monarch.

Exasperated, Lewis convened a diet in Frankfurt in May 1338. The progeny of this diet was a manifesto called Fidem Catholicae. This document claimed that imperial authority comes from God alone. In August of the same year, he called another diet and promulgated a law called Licet Iuris. It insisted that imperium did not require the papal approbation. When peace between Lewis IV and Philip VI was restored in 1341 , peace with the papacy did not follow.

Lewis IV continued to have problems with several of the electors. The principal antagonist to Lewis IV in Germany was John of Bohemia. Lewis IV had unlawfully annulled the marriage of John's son, Henry to Margaret, daughter of Henry, Duke of Carinthia and Tyrol in 1342.

${ }^{22}$ Guillaume Mollat, The Popes at Avignon, 1305-1378 9th ed., trans. Janet Love (New York: Thomas Nelson and Sons, 1949), 222. 
This act not only infuriated John; it also infringed on the spiritual autonomy of the church to annul marriages.

The year of the annulment, 1342, coincided with the election of Pope clement VI. Unlike Benedict XII, Lewis IV now faced another implacable foe. Having spent much of his life as an instrument of the royal French court, Clement VI was well versed in the workings of secular administrations. He recognized the fact that the papacy needed a secular ruler to wield universal imperium. The status quo arrangement with the empire in no way benefitted the church. The acts that unfolded between 1342 and 1346 are interesting for two primary reasons. First, they illustrate vividly how both the power of Church and Empire had waned in relative importance to other European powers. Secondly, they demonstrate how the whole dynamic between pope and emperor had changed, how the gulf between reality and theory had widened.

Clement VI believed that imperium emanated from God, but was channeled through the pope. In one of his sermons, he refers to the river alluded to in Ecclesiastes which always returns to its source; imperium worked the same way. ${ }^{23}$ Like John XXII, he denied that Lewis IV had ever rightfully been emperor, because he had never received papal approbation. In clement's mind, there was no emperor, and until one could rightfully be seated, the pontiff was verus

\footnotetext{
145 .

${ }^{23} \mathrm{Clement} V I$, "Sermon $40, "$ in wood, Ideas and Ponitficate,
} 
imperator and the possessor of imperium. On this authority, he proceeded with the unenviable task of finding a suitable candidate -- unenviable because the nominee would have to be amenable to the German electors and himself. ${ }^{24}$

The two attributes which clement VI sought in his candidate were strength and pliability. Unfortunately, these attributes exist in unified harmony within few men of any age. The obvious candidates for emperor all had marks against them. The imperial pretender, Lewis IV had long demonstrated his disrespect for the papacy. John of Bohemia was too independent and unreliable. Philip VI of France was perceived by clement as being too dominant a player to accept the role of defensor Ecclesiae. Edward III had sided with Lewis IV, and furthermore, the $1340^{\prime} \mathrm{s}$ were no time for a good Frenchmen like clement to establish friendships with the English. Clement VI's obvious choice from the beginning was Charles of Moravia. Not only did he have the political stature to be emperor, but he had been a student of Pierre Roger as a youth. Most importantly, he had a claim through his father, John of Bohemia, who was the son of the last crowned emperor, Henry VII.

The difficulties in selecting a suitable candidate were minor compared with the difficulties involved in reining in the disparate Electors. After all, they had agreed (in the late $1330^{\prime} \mathrm{s}$ ) to the imperial mandates

\footnotetext{
${ }^{24}$ Ibid.
} 
Catholicae Fidem and the Licet Iuris, which emphasized the autonomy of imperial elections and the imperial office. The electors had more to lose than gain by allowing papal intervention. Clement VI demonstrated that he was prepared to use every precedent employed before in the papal/imperial struggle to resolve the matter.

Through homiletic discourse and papal nuncios, clement VI reminded the College of Electors that it was Pope Gregory $V$, who near the end of the tenth century, founded the College of Electors.

Gregorius $V$ tempore otthonis imperatoris convocatis et requisitis principibus Alemaniae septem electores instituit officiales ipsius curiae imperialis: quattour laicos, ut regem Bohemiae, ducem Saxoniae, comitem Palatinum, et marchionem Brandenburgensem, et tres clericos, archiepiscopym, Maguntinensem, Coloniensem et Treverensem.

The electors were quick to point out that since Gregory $V$ had given them the right to elect an emperor, it could not be rescinded. ${ }^{26}$ clement VI granted them that right, but he stated that imperial election made one king of the Germans, not rex Romanorum. Rex Romanorum was derived from the

25 "[Pope] Gregory $V$, in the time of Emperor otto, called and required the seven electores from the German principates, installed as officials of the imperial court: four were laymen, constituting the king of Bohemia, the duke of saxony, the count palatine of the Rhine, and the margrave of Brandenburg, and three religious, the archbishop of Mainz, Cologne, and Trier. Augustinus Triumphus, summa, xxxv. 2, p.206, in Michael Wilks, The Problem of Medieval Sovereignty in the Late Middle Ages, (New York: Cambridge University Press, 1964), 247.

$$
{ }^{26} \text { Ibid. , } 248 \text {. }
$$


papacy, who held the patrimony of Rome. Only after papal approbation does one become Holy Roman Emperor. Clement VI was careful not to push the idea too far, because he feared that it might fracture the whole imperial conception. ${ }^{27}$

In addition to his political arguments, Clement was prepared to argue on theological grounds. The theological training that Pierre Roger received at the University of Paris was especially complete and thorough. His grasp of doctrine and scripture was lauded by his contemporaries. ${ }^{28}$ In his early writings, Roger admitted that he did not think that the pope should in any way modify scripture to reach questionable ends. ${ }^{29}$ Owing to the fact that medieval theologians recognized four ways to interpret scripture, literally, allegorically, morally, and anagogically, Pierre Roger's statement is open to various interpretation as to which of the four senses he was against.

In reality, as pope, clement VI rarely shied away from the use of allegorical interpretation of Holy scripture to convey a point. Political use of scripture was not confined however, to the debate over imperium. There are interesting

${ }^{27}$ Wood, 153.

${ }^{28} \mathrm{John}$ E. Wrigley, "Clement VI before His Pontificate: The Early Life of Pierre Roger 1290/91-1342," The Catholic Historical Review, 61 (October, 1970): 441.

${ }^{29}$ Diana Wood, ". . novo sensu sacram adultere Scripturam: Clement VI and the Political Use of the Bible," in The Bible in the Medieval World: Essays in the Memory of Beryl smalley, eds., K. Walsh and Diana Wood, studies in Church History subsidia 4 (1985), 240 . 
uses of scripture in his collationes concerning the dissident German archbishops, the crusade, the jubilee of 1350, and his many appointments of Cardinals and prelates, and in the creation of the King of the Canary Islands.

In his days as Master of Theology at the University of Paris, he had declared that the Bible alone was free of error. "Hoc enim privilegium Deus solam divinam scripturam habere voluit, ut in ea sola nullum firmentum aut contagium falsitatis." 30 He believed that his arguments were unassailable when properly supported by scripture. Thus, Clement politically used the Bible in three principal ways. He searched for rarely used passages which could give his collationes precedence and distinguish them from age old papal arguments. Secondly, he would translate passages prophetically, that is, he interpreted certain biblical passages so as to foretell events about to happen. Thirdly, he used allegory to hammer home a hypothetical point. ${ }^{31}$

Imperial lawyers stated that imperium preceded the papacy, just as the title of caesar preceded christ, and thus the Holy Roman Emperor operated autonomously, with God's direct favor. To counter these arguments, clement

30 "The privilege of containing nothing full of malice and falsity God has been reserved for Holy scripture alone." This passage was taken from a Clement VI's sermon given on $s t$. Thomas Aquinas Day. Wood, "Clement and the Bible," 240.

$31 \mathrm{Clement}$ was fond of using the examples of solomon, Saul, and David as models of the proto-typical emperor. The persona of Judas was occasionally used to depict anyone who violated the mission of the Holy church, the earthly extension of Christ. Ibid. 
used the arguments of the publicist, Augustinus Triumphus. Triumphus extended the hierocratic theory back to the inception of the nation Israel. He championed Abraham, Noah and Moses as proto-typical vicars. ${ }^{32}$ once writers like Triumphus were able to push this theory back to Adam, they were able to say that there had never been a time when kingship preceded the priesthood. "Unde universaliter sacerdotium fuit ante imperium." 33

Owing to the fact that the old Testament refers to the relationship between the priesthood and the king more regularly than the New Testament, we see it referred to often and effectively. Clement VI used the old Testament extensively to construct arguments against Emperor Lewis IV and to amplify his own ideas on power or authority. His sermons were developed by lifting distinctions and subdistinctions out of a biblical passage so as to create motifs which supported his point. ${ }^{34}$ Frequently, a literal translation of biblical texts was employed to make a direct political statement, as in the sermon he preached concerning his support of Charles of Moravia, in which he used a passage from Kings I, 2:12, "Solomon sat upon the throne of 539.

${ }^{32}$ Augustinus Triumphus, Summa, xxxvii. I, 219., in Wilks,

33 "From the beginning of the universe the priesthood preceded the emperor." Augustinus Triumphus, summa xxxvi. 215, in Wilks, 215.

34 Wood, "Clement and the Bible," 239. 
David his father; and his kingdom was firmly established."35 clement believed that the old Testament example of solomon choosing his successor as king of Israel set a strong precedent. As st. Augustine pointed out, Israel was the only nation where the ruler was anointed by the priesthood before he assumed office. ${ }^{36}$ The Empire was universal and the emperor must receive unction to assume the title. As clement VI saw it, to receive unction was tantamount to receiving approval. The right of the priesthood to accept or reject a candidate for office was granted by God. The fact that David was chosen as the least of Jacob's sons seemed to support the right to pick the candidate of the priesthood's choosing. ${ }^{37}$

To undercut the notion that the power to rule, imperium, was granted by the people, Clement VI once again pointed out that the right of saul to be king "had been given 'not at the election of the people but at the petition. 38 Thus the German Electors could petition for a candidate whom they had elected to be accepted as emperor, but they could not make him an emperor.

Clement VI did not wish to totally emasculate the emperor, as Pope Gregory IX and Innocent IV had done less

${ }^{35}$ Ibid. , 240.

${ }^{36}$ st. Augustine, Enarrationes in Psalmos, (Westminster, Maryland: The Newman Press, 1960), 19.

${ }^{37}$ Wood, "Clement and the Bible," 240.

${ }^{38}$ Ibid. , 243. 
than a century prior. Clement was willing to grant imperial sovereignty, but the purpose of this sovereignty was pro bono rei publicae only. In claiming the right to secular intervention when the emperor failed in this task, Clement borrowed from Esther, "And God changed the king's spirit into mildness." 39

Nowhere is scripture more deftly employed by clement VI than in his homilies in consistory concerning the imperial claimant, Lewis IV and his successor to the imperial office, Charles IV. There is constant reference in his collationes to the two swords of Christendom mentioned in Luke, 22:38, which supported the pope's claim that the priesthood holds both swords, one spiritual, and one physical. Clement VI applied other Biblical passages allegorically, which he believed furthered or upheld papal claims. Common themes for his collationes were "the ship of st. Peter, the seamless garment of Christ, the sheepfold and the good shepherd, the Noah's ark, the fishing net, [and] the stone which the builders rejected." 10 Few men of the fourteenth century were prepared to wage battle with clement VI, the "maximus sermocinator verbi Dei," over interpretation of scripture. "1

${ }^{39}$ Ibid. , 244.

10 Ibid. , 238-239.

11 This sentiment was expressed by Aymeric de Peyraco, Chronicon, cited in Baluze. Diana Wood, "The Sermon Literature of Clement VI" Studies in Church History II (1975): 163 . 
The most thorough treatment by clement on the supremacy of the papal auctoritas can be found in a sermon he gave at Vincennes before his pontifical election. It was presented at a council convoked by Philip VI in December of 1329, to address the matter of hostilities between prelates and nobles over rights and privileges. ${ }^{12}$ Although the audience was not imperial, it nevertheless provided a propitious venue for Pierre Roger to espouse his views concerning the worth of secular authority.

Roger's remarks were intended to counter arguments presented by Pierre de Cugnieres, a representative of the barons. Pierre de Cugnieres' thesis stated that comparing Church and state jurisdictions was the same as comparing "the sun and the moon, heaven and earth, gold and lead." In other words, there are no comparisons. 13 The over arching theme of Pierre Roger's rebuttal was borrowed from Acts 5:29, which states, "We ought to obey God rather than men." His sermon stated in no uncertain terms that the Church was supreme, because it drew its power from a higher font. Roger countered those who argued for separation of jurisdictions by saying that the two jurisdictions are congruous, and that the congruity can be proved by "divine, and natural law, canon, and civil law, from custom, and from

$12 \mathrm{John}$ E. Wrigley, "Studies in the Life of Pierre Roger (Pope Clement VI) and of Related Writings of Petrarch" (Ph. D. diss., University of Pennsylvania, 1965), 464.

${ }^{13}$ Ibid. , 450 . 
privilege."14 While the temporal lord has temporal sovereignty, the spiritual lord enjoys both temporal and spiritual sovereignty. Finally, as a threat, Roger stated that historically, when temporal lords disregarded ecclesiastical jurisdiction, thus jeopardizing the integrity of that institution, insurrection amoung the people has been the consequence. ${ }^{45}$ As testament to Roger's persuasiveness and oratorical ability, the French Church came out of this council with its jurisdiction unimpaired.

While clement VI was well prepared to argue along theoretical lines, he also recognized when a situation warranted realpolitik. He unashamedly negotiated with Lewis IV and his ambassadors, while promoting the claim of charles of Moravia, hoping to bring about an accord at the last minute. ${ }^{46}$ The obstinacy of several of electors compelled Clement VI to resort to bribes and threats. Archbishop Baldwin of Trier proved a particularly impudent foe. In the four years between clement VI's accession and the election of Charles of Moravia, the Elector Baldwin of Trier had his excommunication lifted, was given gifts of money, and otherwise courted by $\mathrm{Clement}$ and papal legates for his vote. Clement VI had to wrest renewed pledges from John of Bohemia and Baldwin of Trier to prevent them from bargaining with

\section{${ }^{4}$ Ibid. , 464 .}

${ }^{45}$ This passage was taken from a sermon that Clement VI delivered at Vincennes in 1329. Ibid., 502 .

${ }^{46}$ Wood, Ideals and Pontificate, 151. 
Lewis IV as late as the spring of 1346. In addition to his problems with Baldwin, Clement VI was forced to depose Henry of Virneberg, Archbishop of Mainz, for his steadfast allegiance to Lewis IV. It is evident, as Diana Wood suggests, that each participant in this imperial struggle was simply keeping his options open. ${ }^{47}$ The electors realized that they were arguing from stronger positions than a century prior.

With Henry of Virneberg unseated, and the other electors either persuaded or bought over, Clement VI proceeded with the election process. It is insightful to review briefly the life of the man who would be emperor, Charles of Moravia, because it was through his unique character that $\mathrm{Clement} V I$ was able to orchestrate his whole plan. A study of his life also shows how this "priest's emperor" went on to become one of the most independent emperors, as demonstrated by his Golden Bull of 1346 .

Charles was born on 14 May, 1316. His mother was Elizabeth, daughter of Wenceslaus II, King of Bohemia. His father was John, son of Henry VII, emperor, and Margaret, daughter of the Duke of Brabant. The would be emperor Charles IV was introduced to the French court through his father's sister, whom he had betrothed to the King of France. At the age of seven, he was sent to the French court. That same year his aunt died but he remained in

${ }^{47}$ Ibid. , 154-55. 
France owing to King Charles IV of France's love of him. His taste became decidedly French. This is typified by young Charles's dislike for the English. He was promised to Margaret, called Blanche of the house of Valois. He found himself in favor once again when King Charles died and Blanche's brother, Philip, became king.

At about this time, Charles came into contact with Pierre Roger. His childhood recollections of Roger show his admiration. He states in his diary, "The abbot's [Pierre Roger's] facility of speech or eloquence so pleased me that day, and seeing him and hearing him gave me such devout and peaceful prayerfulness, that I began to think 'Why is it that so much grace is poured into me from that man?' At once I acquainted myself with him, and he treated me kindly and fatherly, often teaching me the sacred scriptures." 48 It is said that Roger once predicted to Charles that Charles would one day be emperor, to which Charles replied, "Before that happens you will be Pope."49 This mutual friendship and respect only strengthened with the passage of time. Like most boys his age, he longed for battles and opportunities to show his budding manhood. He left the royal court of France to follow his fortunes with his father John into Italy. He recounts in his diary that Italy

${ }^{18}$ Charles IV, Diary in Bede Jarrett, The Emperor Charles IV (New York: Sheed \& Ward, 1935), 35.

${ }^{49}$ Ibid. , 60. 
provided him with many intrigues and battles. After either winning concessions or making treaties with many of the Italian cities, they travelled northward through Tyrol where they visited their family. They made peace with the Duke of Carinthia, and then returned to Bohemia. Charles states in his diary that he had been away from his home for eleven years. His mother Elizabeth had died while he was away. John of Bohemia's vision had been diminishing for some time, but it was during a return visit to Italy that he totally lost his sight. Charles gained from his father's loss. Father and son went to France in 1344 for two reasons. First, to find a remedy for John of Bohemia's blindness. The second reason was to explore their options versus the inexorable Lewis IV. Charles was in Avignon again to map strategy with Clement VI in 1346. Though John lost his sight, he never lost the chivalric spirit. Froissart waxes romantically on John's quixotic death at the battle of crecy and Charles's less than chivalric retreat. ${ }^{50}$

With John's death, Charles became King of Bohemia in 1346. In the same year, with clement VI's help, he staked his imperial claim. Before clement VI would give approbation, he demanded that Charles IV promise to perform several tasks for him. One task was to eliminate Lewis IV.

${ }^{50}$ Froissart, Chronicles ed. Betty Radice, (New York: viking Penguin, 1987), 90 . 
The second requirement was that charles IV should "administer imperium in Italy."51 Lastly, he set strict limits on the coronation ceremony in Rome, fearing that a successful imperial campaign might erode what little papal control still remained. Charles was to stay in Rome only one night. Charles IV agreed to all of Clement's conditions.

Clement purposefully tried to muddle the distinctions between election to rex Romanorum and the promovendam to emperorship. As Walter Ullmann stressed, the procedure created by Innocent II was a two step process. As Innocent III envisioned it, the election elevated one to royalty, approbation transmitted imperium. ${ }^{52}$ Clement $V I$ made the two steps seem linked, as though one depended on the other. The imperial election took place on 11 July 1346. Charles IV marked the beginning of his regnal years as 6 November, the approbation date. He was crowned in Bonn on 26 November, 1346. Lewis died on 11 October 1347. In 1348, Charles made a series of pacts with Edward III, descendants of the Hapsburgs, Hohenstaufens and Wittlesbachs. He had a proper election in Rome in $25 \mathrm{July} 1349$. In 1349, the League of Swabian cities gave their support to Charles.

A common claim at the time was that charles owed his crown not to clement, but to the French king, who held

\footnotetext{
${ }^{51}$ wood, Ideas and Pontificate 160.

${ }^{52} \mathrm{Ul} l \mathrm{lmann}, 666$.
} 
incredible sway over the Avignonese papacy. Still other contemporaries claimed that he was a pfaffenkönig, or pope's emperor, unable to act independently. Many writers have criticized Clement's choice of Charles, because after his election and approbation, Charles centered most of his attention on being king of Bohemia and not emperor.

Clearly, there was a grand evolution of thought on imperium and auctoritas. The complexities of the idea of imperium in $\mathrm{Clement} V I$ 's time would have bewildered ss. Ambrose and Augustine. The ingenuity of the papacy in making its theoretical power substantive, helped elevate the Church to the great heights of the thirteenth century. When lay scholars began to sift through the theoretical layers of accretions, they realized that the papal/imperial argument was akin to comparing apples and oranges. Imperium was de facto, auctoritas was spiritual and hypothetical. The diplomatic triumph of clement VI turned on his ability to manipulate existing formulas for imperial election and to adapt his plans to match the incongruities of the fourteenth century. 
CHAPTER I I I

POPE CLEMENT VI'S IDEA OF CRUSADE AND ITS PRACTICALITY

The fourteenth century was one of painful metamorphoses for western Europe. This century was grounded in every sense in Medieval unity, but cultural and political diffusion became increasingly more pronounced as the century wore on. In the single time frame of the fourteenth century, one sees the weakening of the universal Church, the reduced usefulness of chivalry, and the dilution of feudalism, transfixed by the growth of nationalism, the germination of realism, and the nativity of secularism. No single event brings one to this awareness more readily than the attempt by the fourteenth century papacy to resurrect the impetus for crusade. The crusades did not simply begin with Pope Urban II's call to arms at clermont and end with the fall of Acre. The completeness of the historical record concerning Pope Clement VI's endeavor to recapture the Holy Land provides an accurate paradigm of these changing realities.

Crusading evolved greatly in ideal and in practice from its nascence in the eleventh century through the fourteenth century. While the central theme remained the same, the reconquest of the Holy Land, the means of attaining that end changed. In addition, offshoots had sprung from the main branch of the great crusades of the 
twelfth and thirteenth century. These lesser branches surged toward the capture and recapture of Christian lands throughout much of the known world.

The successes of the earlier crusades were owed in large part to good logistical planning and cooperation. These earlier crusades were blessed with the advantages of better funding and greater economic stability. More importantly, the relationships between the leading monarchs of Europe and the papacy were more amicable. Intangible, but no less palpable, was the deep level of spirituality in western society. By alloying these elements, the crusades of the earlier centuries were elevated from ideal to action. The fourteenth century idea of crusade was framed in the ideas and practices of earlier attempts to recapture the Holy Land. These earlier forays to the East occurred at a time when the papacy was beginning to assert the fullness of its might near the end of the eleventh century. When the call went out from Clermont in 1095 to mass for a passagium generale or general march on Jerusalem, it achieved a great reception among western Christians, rich and poor. Much of the impetus for crusading grew out of the larger peace movements promoted by the church in the eleventh century. Feudal warfare increasingly tilted toward fratricidal confrontations. Through the peace movements and crusading opportunities, it was hoped that this violent impulse could be rechanneled to more beneficial ends. Clearly, the most successful crusade was the first 
one, begun in 1097 C.E. Spurred on by spiritual fervor and desires for personal enrichment, the French led forces confronted and surmounted several redoubts on their way to the Holy City. Nicaea fell under the weight of western forces. Victory for the crusaders was also achieved at Dorylaeum, opening up a path through Asia Minor. Edessa, a fortified city in Armenia, offered some resistance but it too was overtaken by the Normans. Baldwin of Boulogne left the crusade at this point, beginning a trend which involved the establishment of personal kingdoms in the East based on the western feudal model. Baldwin's desertion provided a precedent which in the long run diverted precious resources from the main goal, the capture of Jerusalem. Following Baldwin's lead, Bohemund stayed behind in Antioch after its capture. Godfrey of Bouillon and Raymond of Toulouse were the only marquis leaders remaining when French forces reached Jerusalem. The city fell relatively quickly and a bloodbath ensued: "our men entered the city, chasing the Saracens and killing them up to solomon's Temple, where they took refuge and fought hard against our men for the whole day, so that all the temple was streaming with their blood." Continued in-fighting among these two Christian leaders prompted Raymond to leave Jerusalem to Godfrey and to pursue his fortunes elsewhere. The success of the First

lanonymous, The Deeds of the Franks and the other Pilgrims to Jerusalem ed. Rosalind Hill (New York: Thomas Nelson and Sons LTD, 1962), 91. 
Crusade was due in part to disorganization among the Muslim leadership. With the fall of Jerusalem, the Latins employed negotiation and conciliation with the Muslim leadership to hold the status quo.

The conquests of the First Crusade prompted a flood of pilgrims to the Holy Places. Some stayed, but most returned home. The attempts at colonization were tenuous. Support systems sprung up to meet the needs of these new perengrinators* to the Holy Land. Two enduring religious orders which served to meet the needs of the pilgrims were the Knights of st. John or Hospitallers, and the Knights of the Temple or Templars. The destinies of both orders were interwoven into the fourteenth century crusade scheme but for different reasons.?

When Edessa fell to revived Muslim forces in 1144 , another call went forth to stem the tide of Muslim hegemony. Western Christians responded positively to Pope Eugenius III's call for a second crusade. Spurred on by the entreaties of the Pope and luminaries like Bernard of Clairvaux, a joint Franco-German force assembled at Constantinople. After some intrigues with the Byzantines, they crossed the Bosporus into Asia Minor. Supply lines

The Hospitallers served as a central banking and management corporation for crusading activities in the fourteenth century. The Templars were destroyed by Philip IV of France in 1312. Anthony Luttrel, "The Hospitaller at Rhodes, 1306-1421," in A History of the Crusades vol 3, ed. Kenneth $M$. Setton and Harry W. Hazard (Madison, Wisconsin: The University of Wisconsin Press, 1975), 278. 
were inadequate, and the resolve of the French and German monarchs proved too fragile to endure the mission. Instead of trying to regain Edessa, the remaining crusading forces assembled and attempted an attack on Damascus. The city was too well fortified, and the Christian forces were soundly defeated. The inglorious end of the second crusade demonstrated to the papacy the need for added control. Rumors from the First Crusade made it known that great wealth could be achieved by going on crusade. Increasingly, we see crusaders leaving their homes, full of spiritual fervor, only to have it replaced by greed and speculation. The Third Crusade, begun in 1189, seems to have had the best chance to retake Jerusalem. By linking the forces of the emperor, Frederick Barbarossa, the French King, Philip Augustus, and the English King, Richard the Lionhearted, it was hoped that the Holy Land could once again be won over. The whole quixotic affair achieved very little. The aged Barbarossa drowned before ever reaching Jerusalem. Philip Augustus and Richard the Lionhearted achieved the greatest victory of the Third Crusade by taking Cyprus late in 1189. They were also successful in taking the port city of Acre. Philip retired from the crusade complaining of ill-health and returned to France. Richard I lingered on, with the idea of retaking Jerusalem. When military success became impossible, he took up negotiations with the Muslim leader, Saladin. The only lasting result of the negotiations between Saladin and Richard I was that Christians could 
visit Jerusalem, but it was to remain in Muslim hands. The papacy realized that ultimate success in the Holy Land was contingent upon the compliance of secular leadership with the original mission, the relief of Eastern churches and the recapture of Jerusalem. Early crusade theorists, however, were unable to correct this problem. From the First Crusade onward, the degree of fidelity to the papacy declined, and the plans of crusaders became more pragmatic. The fractious nature of the disparate crusading armies contributed to their inability to gain any lasting success. When Muslim forces were able to unite their strength, or one Muslim leader, like Saladin, could achieve military superiority over his competitors in the Levant, the chances of a Christian victory were diminished considerably.

The crusading impulse lost all direction with the promotion of the Fourth crusade. The goal was still to recapture Jerusalem, but a new strategy was now employed. Crusading theorists believed that if they could destroy the hegemony of the Mamluks of Egypt, at that time the strongest center of Muslim power, then Jerusalem could be more easily assailed and controlled. When the crusaders arrived at Venice to be transported to Egypt, they were held, for all intents and purposes, hostage. The Venetians had no intention of attacking their lucrative trading partner, the Mamluks. Through shrewd machinations, the Venetians were able to redirect the crusaders to Dalmatia, where they quashed the navies of pirates operating out of the port of 
$\operatorname{zara.}^{3}$

Upon completion of this task, the crusaders were again diverted from the Holy Land. A Byzantine imperial pretender, Alexius Angelus, petitioned the crusaders to help restore him to the imperial throne, which he claimed to have been unrightfully denied. He pledged great rewards to any crusaders who would assist him. The Latins moved in, and after significant political and military intervention, the crusaders set up the first Latin ruled government of Byzantium. Realizing the possibility for ending the East/West schism, the papacy eventually threw in its support .

The whole notion of crusade had taken on new connotations by the mid-thirteenth century. Spiritual motivation was brazenly jettisoned in favor of material gain and lust for power. The role of the papacy in crusading had been reduced to that of simple approbation. The sporadic efforts to start new crusades in the thirteenth century never fully got off the ground.

The numerous attempts to launch successful crusades in the thirteenth century all came to nothing. The Fifth Crusade, begun in 1217, was designed along the lines of the Fourth Crusade. The papacy still believed that by destroying the Muslim Caliphate in Egypt, Jerusalem and the whole Palestinian area would fall to Christian forces.

${ }^{3}$ Hans Eberhard Mayer, The Crusades 2d ed., trans. John Gillingham (Oxford: Oxford University Press, 1988), 199. 
The Fifth Crusade, the last initiated and led by the Church alone, was made up of a multi-national army. The crusade began on a good note when it scored a resounding victory against the Mamluks at Damietta, a town in the Nile Delta. After wasting a year in the city arguing over booty and future military strategy, the order went out to begin the second phase of operations. When Christian forces marched out of their fortified city and began their march up the Nile, they floundered. Poor Christian leadership doomed the project. Outmatched and out maneuvered, the christians were forced to sue for peace." Disillusionment reigned, but crusade preaching continued.

While Western Christendom enjoyed varying degrees of prosperity and solidarity during the crusading period, its eastern counterpart faced a constant struggle for survival. Several complex elements bound the two Christian factions together. These elements determined in large measure the success or failure of any given crusade. Thus they bear some examination.

The chances for the success of any crusade was dependent on the cooperation of the Byzantine state. In the twelfth and thirteenth centuries, eastern support could generally be counted on, if for no other reason, than to slow the inexorable march of Muslim domination in the region. The military defeat at Manzikert in 1071, at first

$$
{ }^{4} \text { Ibid., 226-27. }
$$


glance seems to mark the decline of this great empire, in actuality it gave Byzantium a future by making it more compact and more easily controlled. Though more compact, it still was not safe from the waves of newly invading peoples. As Ostrogorsky points out, several elements came together in the second half of the eleventh century which sounded a death knell for the empire. While the demise of the empire was slowed by revisions in the military and political arrangement, increasing incursions by Arabs, Cumans, Bulgarians, Serbians, and even western Christians, precluded any lasting peace, and slowly eroded away the power base of the empire. 5

In the twelfth and thirteenth centuries, the Byzantine state was weakened by a lack of central political cohesion, by ecclesiastical discontent, and by external pressures. While this period is often called the Golden Age of the Byzantine state, in it can be found the seeds of its demise.

As has been previously stated, the crusades were ruinous for Byzantium. Not only did these holy wars place Constantinople in harm's way, as thousands of knights and pilgrims made their way east and crossed at the Helispont into Asia, they also paved the way for the increased presence of Venetians and Genoese in the eastern Mediterranean. Even well-meaning crusaders found themselves

${ }^{5}$ George Ostrogorsky, History of the Byzantine state rev. ed. with foreword by Peter Charanis, trans. Joan Hussey (New Brunswick, New Jersey: Rutgers University Press, 1969), 145. 
being allied against the "foreign" Greeks. The misdirected Fourth Crusade provides ample evidence of the mutual mistrust inherent during the crusading period. Economic and political concerns overrode piety. As a product of this crusade, the Latin Kingdom of Constantinople was set up. The papacy rejoiced as it saw an end to the schism. In sixty years, however, the Greeks were back in control. And they now recognized the complete folly of placing their hopes for security in the hands of westerners.

By the end of the thirteenth century, most of the land captured by the earlier Christian crusaders had been reclaimed by the Muslims. Acre, one of the last western strongholds in the East fell in 1291. Four factors spelt the end of active French participation in the Levant, a lack of interest, domestic problems, inadequate funding, and diminishing returns. The fall of Acre ended, at least symbolically, French influence in the region.

At the dawn of the fourteenth century, Christian holdings in the East amounted to three principal areas of influence. The first encompassed the sea lanes between Cyprus, Alexandria and syria. Cyprus had been controlled originally by Guy of Lusignan, and then by his descendants. The second area was the little kingdom of Cilician Armenia, governed by Eastern Christians. The last area, called Romania by its contemporaries, was a less well defined area.

${ }^{6}$ Mayer, The Crusades, 286. 
It's southern boundary was roughly the islands of Crete and Rhodes, Constantinople and the port city of Durazzo defined the northern border. It contained most of Greece and its adjacent islands. This geographical patchwork arrangement meant that there was continual overlapping of spheres of influence. Consequently, Christians in these three areas were often just as content to fight among themselves for economic and political hegemony, as to unite for a unified Christian cause.?

The island kingdoms were fairly secure from Muslim domination because the Mamluks were not a seagoing people. Up to this point, the western policy had been to try to check the power of Mamluk caliphs by blockading the Egyptian and southern Levantine ports. This concept of containment was an outgrowth of the strategic planning of the Fifth Crusade. The efforts were ineffective because Genoese and Venetian traders refused to give up lucrative trading opportunities in the region, with not only the Egyptians, but also the budding markets of India and China.

The biggest maritime threat came not from the Mamluks, but their northern neighbors. The emirs of Anatolia and the Levant were beginning to assemble small fleets by the beginning of the fourteenth century. Turkish emirs were not content to stop at the sea of Marmara or the Levantine strand. Occasionally, their help was solicited by warring

Torman Housley, The Avignon Papacy and the Crusades (New York: Oxford University Press, 1986), 9-10. 
Byzantine factions to be used against each other. They were invited into Greece and Macedonia in large numbers and fought along side Andronicus III and John Cantacuzenus.

Once these seeds were sown by the Byzantines, further Muslim proliferation in Thrace and Greece were inevitable. ${ }^{8}$

Cantacuzenus' extreme distrust of Latins precluded any overtures of peace or union with the West and drove him into the arms of the various Turkish emirs.

At the end of the thirteenth century, while the Byzantine state struggled with political instability and a divisive religious struggle called the hesycast controversy, western Christendom staggered under the weight of an even greater assault. No aspect of Christendom was untouched by the papal humiliation at Anagni, its flight from Rome, and the subsequent domination of the church by the French monarchy. Separated from its patrimony of Rome, the papacy faced severe financial restraints. Fiscally and politically limited, the wandering papacy was more concerned with preserving its own existence in southern France, than strengthening the viability of the faith one thousand miles east. 9

The difficulties in preaching the need for a crusade in these hard times were great. The outright revolt of the most important crusading body, the French, combined with the

${ }^{8}$ Ostrogorsky, Byzantine state, 525-26.

'Geoffrey Barraclough, The Medieval Papacy rev. ed., (New York: W. W. Norton and Company, 1979), 139. 
drastic decline of western imperial influence, reduced the availability of monies and men for the crusading cause. Less than a century prior to the fourteenth century, the papacy had reveled in its influence over the leading monarchs of Europe. History indicates that the failure of the medieval papacy was due, in many respects, to its increased secularism. Had it allowed the political process freer rein, its force in moral and spiritual matters would have been stronger.

Nothing demonstrates how detrimental the secular minded papacy was to crusading than the destruction of the imperial office. While the papacy emerged from its conflicts with Frederick II stronger, it also weakened a valuable asset of the papacy, its seeming autonomy. In one fell swoop, the papacy defeated a formidable foe and a potentially strong ally. With the defeat of Frederick II, the ideal of the universality of a Holy Roman Empire was openly assailed. Any theoretical dominion he may have claimed in the East was openly assailed. The fourteenth century witnessed the pitiable struggle between a rudderless papacy and a further weakened imperial office. As a result, we see little effort expended by the papacy to employ the emperor in crusading during the Avignonese period.

The interests of the English in crusading was greatly diminished at the beginning of the fourteenth century. Throughout most of thirteenth century, England had been embroiled in civil disputes. In addition, England's 
relationship with the church had been strained by the repeated intervention on the part of the Church in the areas of politics and taxation. Yet another reason for England's reluctance to become involved in crusading stems from its deep distrust of the French. With warranted trepidation, we see both countries keenly eyeing each other, unable to commit fully to any crusading plans. So it is with little surprise that we see England playing a very minor role in the papacy's plans for a crusade in the fourteenth century.

Just as the crusades had succeeded, to some degree, in limiting the fratricidal warfare of earlier centuries, it was hoped that this earlier precedent would work to avert further political instability in the fourteenth century. The first major promotion for a crusade in the fourteenth century came from Pope clement $V$. He was elected on the fifth of June, 1305. His election was more the result of his ambivalence to the various religious divisions of the time, and his favorable relationships with the French and English monarchs, than any remarkable ability. ${ }^{10}$ Meager though his talents and resources may have been, it was clement $V$ who reinvigorated the idea of crusade in the fourteenth century.

Clement $V$ believed that the only hope for mounting a large enough crusade to dislodge the Muslims from the Holy Land had to come from France. The enfeebled papacy was in

\footnotetext{
${ }^{10}$ Ibid. , $142-43$.
} 
no position to command any such action. Many historians have highlighted his understandable aversion for conflict with Philip IV, which in turn fed his inability to promote papal concerns." Given the onerous state of Church affairs, and Clement $V^{\prime}$ 's precarious position as junior partner to Philip IV, all Clement could do was maintain a holding action to prevent further erosion of papal power. Philip IV continued to insist on two points which were deleterious to this power. The first point concerned the condemnation of Boniface VIII, and absolution for Guillaume of Nogaret for his role in the attack on Boniface at Anagni. secondly, and most notable and contiguous to the matter of crusade, was Philip's demands to have the Knights of the Temple or Templars disbanded for malpractices. For six years, Clement held out against Philip's demands, but he eventually acceded in 1311.12 While this action weakened the papacy, it ended the gridlock between church and state, and allowed clement to begin working on other projects.

Clement envisioned a grand crusade which would accomplish two things. He wanted to reconcile political differences between the leading monarchs of Europe. Second, he desired to regain the imagery of the pope as God's guidon bearer on Earth. He favored a three step operation for a

${ }^{11}$ Guillaume Mollat, The Popes at Avignon: 1305-1378 9th ed. trans. Janet Love (Edinburgh: Thomas Nelson \& Sons, 1963), 6; Yves Renouard, The Avignon Papacy, 1305-1403 trans. Denis Bethell (Hamden, Conn.: Archon Books, 1970), 20.

${ }^{12}$ Barraclough, 143 . 
recapturing of the Holy Land. The first step called for the eventual recovery and defense of Frankish Greece and Armenia. The second point of the operation was to maintain and strengthen the blockade on the Mamluks of Egypt. The culmination of his plan was to be the eventual recovery of the Holy Land with a general passage. ${ }^{13}$

clement believed that if he acquiesced to Philip's demands, Philip would, in turn, lead the general crusade. Clement correctly surmised that no other king in Europe had the finances, supply base, and army that Philip commanded. clement $V$ realized that he lacked support outside of France. Thus, the papacy was bound by necessity to the French monarchy, because no matter who led the crusade, most of the money needed would come from France in the way of tenths. So began a trend in fourteenth century crusading, where the French king was the pivotal figure on which success depended. This is a crucial point, because this position was perpetuated into the long reign of John XXII. BY concentrating all its aspirations on a single man, the papacy limited its options, both in planning and in recruiting others to the crusading standard. Clement $V$ 's approach was conservative, but considering his plight, it was reasonable.

The Council of Vienne in 1312 marks the official beginning of Clement $V^{\prime}$ 's big push for a crusade. Though the

\footnotetext{
${ }^{13}$ Housley, 12 .
} 
council was called for political reasons (basically, the dismantling of the Templars), it dealt in addition with ecclesiastical matters, namely, the condemnation of Boniface VIII and reform of the Church and papacy. The only agenda which Clement $V$ was able to promote fully was the resumption of crusading activities. Philip IV, his son, Louis, and son-in-law, Edward II of England all vowed to take up the cross. Clement $V$ called for the collection of six years of tenths to finance this enormous project. Lastly, he called for the organization of crusade preaching. 14

Clement's single victory at the Council of Vienne was short lived. Clement $V$ died less than a year after the council ended in 1314. Presumably, the crusade should have advanced under its own power since commitments had already been made and the finances prearranged. Rank and file Christians prepared for the inevitable assault.

Logically, it was believed, the next elected pope would continue promoting the idea. The royal participants, however, had different plans. Philip IV, consumed by troubles in Flanders and with England, was more concerned with problems at home than abroad. Edward of England was equally occupied by discontent in scotland and French intervention. Lastly, the crusading impetus lost valuable momentum as it took over two years to elect another pope. So while the common people continued to prepare for the

\footnotetext{
14 Ibid. , 14.
} 
eventual crusade, the leaders operated under separate agendas .

With the election of John XXII in 1316, we see the delayed continuation of Clement V's crusading policy. John realized that a crusade lent prestige and increased the power of the papacy. Since John's reign was relatively long, it is sensible to group the crusading activity during his pontificate into three different phases or periods. They correspond with the reigns of the French monarchs Philip V, Charles IV and Philip VI, and encapsulate a period between 1316-1334.15 From his writings, we can infer that John XXII pinned all his hopes for a crusade on the royal court in Paris, about which he wrote, "French power, whose aid is second only to that of God in the needs and expectations of the Holy Land."16 By delegating so much authority to the French monarchs, he limited his own autonomy in conducting the crusade.

Nevertheless, crusading zeal was fervent at the court in Paris. Whether this zeal was inspired by the songs of jongleurs or by a need for adventure, French chivalry responded positively to the pope's call for a crusade. The crisis in Frankish Armenia and the requests for support by the titular Latin princess of Byzantium, Anna of Savoy,

${ }^{15}$ Ibid. , 20.

${ }^{16}$ Ibid., 18 . 
provided strong motivation for the French to come East. 17 Another reason for this desire sprung from the opportunities for political and economic gain in the East. Lastly, the promise of spiritual indulgence still held a strong appeal in the fourteenth century.

Whether John XXII was duped by the promises of the French monarch, or simply turned a blind eye to the progress of the crusade planning can never be known. It was widely rumored at that time that the French king had ulterior motives in collecting the tenths. English writers like Knighton charged that the French monarchy was using the crusading tenth to prepare for war with them. It was implied that the papacy was aware of this and promoted it. 18

These English claims were not completely unfounded. John was a good administrator, and held close contact with the French royal court. He could not have been totally unaware of the fact that the tenths were being redirected. His reticence indicates that he allowed this reallocation of funds. It is unclear whether John XXII feared another Boniface-like struggle with the French monarchy over taxes, or actually wished to bolster the French position. He must have realized that French help in the East would not be

${ }^{17}$ setton, 415 .

${ }^{18}$ Henry Knighton, Chronicon, in Housley, 19. 
forthcoming if there was not peace first at home. ${ }^{19}$

When Philip $V$ of France died in 1322, he was succeeded by Charles IV. The stalling tactics of Philip V, already popularly perceived, were admitted by his successor. Charles IV reported to John XXII that the monies collected from the Vienne tenth had already been spent, and that only a renewal of the grant of tenths could revive the aspirations for freeing the Holy Land. ${ }^{20}$ when this open declaration of reckless spending reached John XXII, and the full extent of this disclosure became known, John XXII was furious, because the tenths collected up to the succession of Charles IV would have amounted to roughly $2,750,000$ pounds. 21 As an able administrator, John XXII could not publicly condone this irresponsible fiscal behavior. He still greatly desired an Eastern policy, however, which in turn required French help. Under the present conditions, he had no choice but to accept past fiscal mistakes. Reluctantly, new tenths were ordered.

Charles IV of France devised a three point plan to recapture the Holy Land. First, he promised to organize a primum passagium to relieve his allies in Armenia. The second step called for a passagium particulare the next year to the Levant. As a final step, he proposed a passagium

\footnotetext{
${ }^{19}$ Housley, 21.

${ }^{20}$ Ibid., 20 .

${ }^{21}$ Ibid., 21 .
} 
generale, which would culminate in a long term retaking of Anatolia and the Levant. ${ }^{22}$ All these plans were contingent on stability, a condition not often achieved in early fourteenth century France. Economic and political disruptions were frequent, and they in turn reduced the funds needed to finance the various crusading projects. Plans were downsized as funds dwindled.

Philip of Valois succeeded Charles IV upon his death in 1328. Philip, realizing the domestic quandary he was in, asked the papacy to relieve him of his crusading vow. He envisioned a less expensive pilgrimage to Spain. But John XXII, and a papal proponent, Pierre de la Palu, impressed upon Philip the urgency of taking up the cross and going east. Philip accepted, undoubtedly aware of the increased money that would be available to him from the tenths. Nevertheless, his spiritual commitment was questioned by $\operatorname{many} .^{23}$

John commissioned a renewal of crusade preaching in 1331. The passagium generale was to proceed before 1334 . During this time, the future Pope Clement VI, then known as Pierre Roger, received much acclaim for the zeal with which he preached this crusade. In 1333, he invited the chivalry of France to take up the cross at the grand gathering of Saint-Germain-des-Pres. The efficacy of his sermon is

${ }^{22}$ Ibid. , 23.

${ }^{23}$ Matteo Villani, Chronica bk. 7, ch.2, ii; 6-7, Knighton, Chronicon vol ii, 476; in Housley, 19. 
evidenced by the large numbers who made a vow that day. ${ }^{24}$

During this period, Roger's reputation for shrewd parlance and crusading fervor grew. He took on an increasingly greater role in promoting John's crusade. He rendered an important service as negotiator between England and France. John XXII realized that Roger's diplomatic abilities, combined with his familiarity of French court, were invaluable assets. On February 17, 1333, Roger proclaimed Philip VI's plans for a crusade before the full consistory of cardinals and the pope. Again, in July of 1333, Roger was back in the pulpit, this time promoting the importance of having Philip VI declared commanding general of the upcoming crusade. The efficacy of the sermon was demonstrated in two ways four days later. First, John XXII formally agreed to allow Philip VI to lead the crusade. Second, he asked Pierre Roger to promote the crusade for the Valois king. At the church of Pre aux clercs, Roger delivered the commencement sermon for John XXII's proposed crusade. After the sermon was delivered, Philip VI took up the cross and accepted the title of commander general in front of the French nobility. Roger's role as chief mediator between John XXII and Philip VI was one of the central factors in his eventual rise to the papacy. ${ }^{25}$

${ }^{24}$ Housley, 24.

${ }^{25} \mathrm{John}$ E. Wrigley, "Clement VI Before His Pontificate; The Early Life of Pierre Roger, 1290/91-1342," The Catholic Historical Review 56 (October, 1970): 460-61. 
A naval league was established by John XXII in 1332 to combat Turkish piracy. This league was a joint effort, promoted by the pope, with the help of the Venetians, Hospitallers, and Andronicus III. In its short life span, the league was successful in its task. The Christian alliance won a dramatic battle against the Turks at the engagement of Adramyttium. The initial successes of the league spawned more ambitious strategies. ${ }^{26}$

John XXII planned a land assault in conjunction with the league's operations. The overland offensive was to commence in 1335. John pinned his hopes for initial success against the Turks in Anatolia on a mere four hundred armed knights. The paucity of military forces allocated for this ground offensive demonstrates both a lack of Western understanding as to the gravity of the situation in the East, and the Pope's inability to raise more substantial forces. When the league disassembled and the constituents returned to their various ports, they were never recalled to service. Like the plans devised by clement $V$, the driving spirit of these plans died with its author, John XXII, in 1334.27

Benedict XII initially continued John XXII policies toward the East, believing that his predecessors plans could

${ }^{26}$ Deno Geanakoplos, "Byzantium and the Crusades, 12611354," in A History of the Crusades, vol. 3, eds., Kenneth $M$. Setton and Harry W. Hazard (Madison, Wisconsin: University of Wisconsin Press, 1975), 51.

${ }^{27}$ Housley, 25-27. 
be salvaged. He continued both the sexennial tithe and the crusade preaching initiated by his predecessor. ${ }^{28}$ In December of 1336, Benedict XII discerned Philip's true agenda. The French monarch now openly demonstrated his lack of commitment to the crusade. As prospects of war loomed large, Edward II of England was recognized as the immediate threat. Benedict correctly perceived that the monies from the tenths were being used against other Christians, so he canceled the collection of tenths. In addition to the French backing out of the plan, disputes had arisen between Genoa and Venice which made passage to the East much more difficult. ${ }^{29}$

Disregarding rhetoric to the opposite, Benedict XII's actual eastern policy consisted of food and economic assistance to Armenia and Greece. He provided indulgences to any who would help fight against the Turks. And lastly, missionaries were sent into Turkish and Egyptian territories in hopes of conversion. ${ }^{30}$

Benedict XII's eastern policy undoubtedly disturbed Pierre Roger. All the progress he had made in advancing the cause of the crusade was now checked. Benedict, picking up on the ideas of Raymond Lull, an early fourteenth century missionary, favored the less expensive idea of sending
${ }^{28}$ Ibid. , 29.
${ }^{29}$ Ibid., 29.
${ }^{30}$ Ibid., 30-1. 
missionaries to the East, especially to Armenia, over the expenditure of vast sums on a dubiously complicated military expedition. ${ }^{31}$ Benedict was not an adventurous sort, thus the legacy of Benedict XII's reign is marked by his efforts at reforming church institutions and strengthening the financial and political situation of the papacy at Avignon.

In the decade of the $1330^{\prime}$ 's, western Europe was engulfed in domestic and economic turmoil. The need for providing aid to eastern Christians seemed secondary to all parties involved, save the papacy. Nothing short of an all out push by a risk taking individual could propel the crusading agenda forward. We find just such a man in Benedict XII's successor.

In 1342 , there was an reawakening of the crusading impetus. It was aroused by the election of clement $V I$ in 1342. Clement VI's conception of crusade was built on the salvageable aspects of his immediate predecessors policies. His advantage was derived from his experience and knowledge of the various phases of crusade planning and execution. Clement was especially aware of the secular end of crusade negotiations. He had represented Philip VI during crusading negotiations in the early $1330^{\prime} \mathrm{s}$. His influence in the royal court was wide. Having been an insider at the royal court in Paris, he knew first hand of the preoccupation of

${ }^{31}$ E. Allison Peers, Fool of Love: The Life of Ramon Lull (London: S.C.M. Press, 1946), 67 . 
the French king and the court in Paris. ${ }^{32}$ without the help of the French king, and the cooperation of Edward III of England, he recognized the need to explore new options and different strategies.

One of the first actions taken by Clement VI upon his election in 1342 was the setting in motion of relief for Christians in the East. His motives were not entirely altruistic. An accomplished student of history, clement recognized the role of crusading as an effective deterrent or alternative to the fratricidal warfare between France and England. By pointing the two combatants toward a more honorable goal, a holy war, their hostilities could be put to better use. Most importantly, Clement realized that the stature of the papacy could only increase by its having a central role in the project.

Clement's writings indicate that he saw the presence of infidels in the East as a threat to the plenitudo potestatis of the papacy. He wrote, "infideles ratione infidelitatis merentur perdere omnem dominium." 33 clement reflected the sentiment of many fourteenth century canonists, that the only valid "right to rule" came from the

32Wrigley, "Clement VI Before His Pontificate," 461-463.

${ }^{33} \mathrm{Cl}$ ement VI, sermon 45, Bibliotheque ste. Genevieve, 240, folio 337v, in Diana Wood, Clement VI: The Pontificate and Ideas of an Avignon Pope (Cambridge: Cambridge University Press, 1989), 193. 
Church: outside the church there was no imperium. ${ }^{34}$ In addition, he promoted punishment of the infidels because they violated natural law by worshipping false idols. Earlier canonists, expanding on Alcuin's teachings, had maintained that forcible conversion of the infidel was unjust. ${ }^{35}$ clement VI denounced any binding affiliation with this earlier doctrine by stating superciliously, that his predecessors did not know how conduct themselves as popes; and that he, with his unique insights into these problems, was better able to discern how to remedy them. ${ }^{36}$ In addition to the canonical deviations in his approach to crusading, a great divergence occurred in Clement's crusading strategy. He ended the long tried attempt to blockade the Egyptian ports of the Mamluks. The principle Christian violator, the Venetians, had no intention of abiding by the blockade. He also gave up on the idea of a passagium generale in the mode of the great passages of the twelfth and thirteenth centuries. Clement, borrowing from his immediate predecessor, correctly criticized these plans as too expensive and unwieldy to attempt with the current instability in Europe. Rather, he

${ }^{34}$ Aegidius Romanus, De Ecclesiastica Potestate ed., Richard Scholz (Weimar: Verlag Herm. Bohlaus Nachf, 1929), 9697.

${ }^{35}$ Hostiensis, Decretals III, xxxiv, 8, fol. 176v., in wood, Clement VI: The Pontificate and Ideas of an Avignon Pope 194.

${ }^{36}$ Wood, Pontificate and Ideas, 195. 
believed that he would have a better chance at a passagium particulare, that is, striking at and securing a single point in the Levant and Anatolia, and then using it as an eventual bridgehead for expanded operations. This idea was initially less expensive and required less dependence on several rulers working in concert. 37

The central crusading accomplishment of $\mathrm{Clement} V I$ reign was the successful launching a Latin Naval League, often called the Holy League. It's military success was contingent upon solid logistical planning and a flurry of diplomatic activity. Many aspects of Curial operations were affected by clement's eastern agenda. The responsibilities for carrying out the negotiations, fund raising, and diplomatic missions were assigned to various men in the Camera and Chancery. When one considers that this crusade planning took place against the backdrop of the opening of the Hundred Years War, it is remarkable that it was able to fulfill all its tasks. Thus, the league's initial victories must be attributed in large part to the efficient manipulation of the ecclesiastical bureaucracy. ${ }^{38}$

The first step required the allying of the major seagoing powers in the Mediterranean basin to Clement's plan. With no marquis leaders coming to the fore to lead

${ }^{37}$ Housley, 32 .

${ }^{38}$ Yves Renouard, "Les Relations des papes d'Avignon et des compagnies Commerciales et bancaires de 1316-1378," vol. 151 Bibliotheque des Ecoles francaise d'Athenes et de Rome (Paris, 1941): 249 . 
the crusade, clement employed a sort of "patchwork" diplomacy, in which he enlisted the help of the Venetians, Hugh of Cyprus, and the knights of St. John. The support of the Venetians was essential to his strategy. Clement empowered Cardinal Guillaume Court with wide ranging capacities to negotiate with the Venetians in $1342 .{ }^{39}$ He was able to attain an agreement with the Venetians to supply six ships. During Benedict XII's pontificate, Hugh of Cyprus had complained in a letter to the pope of the "power and the malice of the Turks," so it was in his best interest to get involved. ${ }^{10}$ Hugh of Cyprus contributed four ships to the league. The Knights of St. John, with more than a little coercion on the part of clement, committed six ships to the venture. ${ }^{41}$ Added to the number of ships mentioned above were the four supplied by the papacy. In order to keep Genoese suspicions to a minimum, and to avoid the impression of overt favoritism toward the venetians, Clement named Martin Zaccaria, a Genoese, captain of the four papal galleys. The Latin Patriarch Enrico d'Asti was named the overall commander of the league, and was given direct instructions not to allow the fleet to deviate from its

${ }^{39}$ Housley, 33.

${ }^{40}$ Wood, Pontificate and Ideas, 177.

${ }^{41}$ Eugene Deprez et al., eds. Lettres Closes, Patentes, et Curiales du Pape Clement VI interessant les pays autres que la France, vol. I fasc. I, col. 129, no. 341, (Paris: Bibliotheque des Ecoles francaises d'Athenes et de Rome, 19601), 294-95. 
mission, a misfortune of previous crusades. ${ }^{42}$

To get the crusade started, Clement VI issued a papal

bull titled Insurgentibus Contra Fidem in september of

1343.43 It formally announced Clement's plans for a

recovery of the Holy Land. The bull announced the beginning of crusade preaching. It also called for the collection of crusading monies. Using earlier commencement bulls for his model, Clement arranged his thoughts in this order: first, he detailed the Turkish threat, next, he proposed how the threat could be alleviated, lastly, Clement suggested how the crusade would be financed. ${ }^{14}$

The matter in hand necessitates a very great outlay of money and calls for larger revenues. The charitable aid of the faithful is of the greatest importance to help it along, and so we are making provisions to invite the contributions of the said faithful with certain spiritual rewards - that is to say, indulgences and remissions."

The bull directed Christian crusaders either to serve over one year in the East with the crusade, or to offer up to the church the monetary equivalent thereof. Clement then decreed the commencement of crusade preaching. He declared a three year tenth for the financing of his plans. Money boxes were to be placed in churches for contributions to the

${ }^{42}$ Jules Gay, Le Pape clement VI et les affaires d'orient (1342-1352), (New York: Burt Franklin, 1972), 36-37.

${ }^{43}$ Housley, 138 .

${ }^{44}$ Ibid., $138-39$.

${ }^{45}$ L.M. Baath, ed., Acta Pontificum Svecica (Holmiae, 193657), in Housley, 138 . 
crusade. ${ }^{46}$ In 1345, Clement enlisted the help of the friars to help preach the crusade. ${ }^{47}$ With the financial logistics in hand, he proceeded with the actual conduct of the crusade.

The initial objective of the mission was to stop Turkish piracy in the Aegean and the Archipelago. The central leader of the Turkish corsairs was Umur Pasher of Aydin. His home naval base was smyrna (now Izmir). Smyrna was a lightly defended town, inhabited ironically by a great many Christian merchants. Under the leadership of Umur Pasher a large degree of autonomy was granted in return for allegiance. Local governmental operations were conducted in a rather laissez faire manner. Though a relatively small town, Smyrna commanded one of the finer ports in that area of the Mediterranean. The safety of the town was assured by the preeminence of Pasher's navy and a fortress that overlooked it. Atiya notes that these emirs were not above aligning themselves with the Christian king of Cyprus to secure the waterways around their ports. Many in the East believed the western Christians to be too occupied to get involved in their affairs. These facts help explain why the city was not strongly defended when the Latin League anchored outside the port of smyrna. ${ }^{18}$

\footnotetext{
${ }^{46}$ Ibid.

${ }^{47}$ I bid. , $155-56$.

${ }^{18}$ Aziz S. Atiya, The Crusades in the Later Middle Ages 2d ed., (New York: Kraus Reprint Corp., 1965), 292-293.
} 
The naval league was very successful in stopping Turkish piracy. The first, great naval victory occurred on Ascension Day, May 13, 1344, when the Turks lost over fifty ships to the Latin flotilla. The smaller Turkish ships were no match for the larger, better armed Western galleys. From 1344 to 1347, the Aegean Sea was considerably safer for shipping and passage. ${ }^{49}$

As part of the overall strategy, Smyrna, the chief port of the pirates was attacked. The first efforts were centered on the destruction of all Turkish craft in the harbor. Then a Latin force landed on the Levantine strand and assaulted the port city itself. With minimal fortification and questionable resolve on the part of the inhabitants, Smyrna fell on the 28 th of October, 1344.50 While the city succumbed quickly to the crusaders, the fortress above the town was never taken during the entire Christian occupation. This victory, the first land victory in syria since the twelfth century, incited great enthusiasm and crusading zeal in the west. Clement VI declared that processions be held in the major cities to acclaim the victory in the East. ${ }^{51}$

As momentum was building for a larger effort in the

${ }^{19}$ Kenneth M. Setton, The Papacy and the Levant 1204-1571 vol. 1, The Thirteenth and Fourteenth Century Memoirs of the American Philosophical Society, no. 114 (Philadelphia: The Society, 1976), 190-191.

${ }^{50}$ Wood, Pontificate and Ideas, 184-85.

${ }^{51}$ Atiya, 301 . 
East, lamentable news reached Clement that on January 17 , 1345, the three leaders, the Genoese Zaccaria, the Venetian Zeno, and the overall commander, the Patriarch Asti had been routed and killed by the Turks in a reckless foray inland from smyrna. The remaining survivors fled in fear back to the city. They petitioned the Pope to send additional help. 52 During the interim period, the christian forces were held together by the leadership of Hélion of Villeneuve of the Hospitallers. The role of the Hospitallers can not be minimized in clement's overall crusading plans. Not only were they responsible for the dispersal of funds in the East. They also played an important role in providing experienced leadership. Most importantly, they performed their duties faithfully for clement VI.

Prior to the vacuum caused by the debacle of January 1345, Clement VI had chosen the weak-minded Humbert II, the Dauphin of Vennois, to follow up the primary successes. clement VI hoped that Humbert could revive the momentum of earlier successes. Humbert fulfilled clement's qualifications for the job in one important way. He accepted Clement's superiority as overall director of the crusade. Humbert's commitment is demonstrated by the signing over of his estates to the house of Valois if he died while on crusade. ${ }^{53}$ In addition, Humbert had proven

\footnotetext{
${ }^{52}$ Housley, 34.

${ }^{53}$ Wood, Pontificate and Ideas, 187.
} 
his loyalty to the papacy by backing Clement in his war against Lewis IV of Bavaria. These attributes must have been important ones to clement, because Humbert did not meet any other qualification.

Humbert was under ecclesiastical censure for an ongoing feud with his archbishop. ${ }^{54}$ He had no experience in leading such an expedition. Nor did he have the resources to sustain a prolonged effort. Evidently, clement believed that, if western fervor for his crusade continued to grow, a snow ball effect would, in time, pull the great leaders of Europe into the fray and sublimate Humbert's initial liabilities. And so we see clement in correspondence with Humbert "sperans. . acquirere multas alias terras infidelium circumposite regionis cultumgue fidei catholice. . dilatare." 155

Clement's hopes rested on a man whose influence and ability was limited. Not only did Humbert lack the leadership qualities befitting a dux; he was incapable of completing a job once started. Humbert was sent to the East to supervise the completion of two tasks. First, he was to strengthen the Christian hold on Smyrna. Secondly, he was to sail up to the Black Sea and relieve the Genoese Christians of Kaffa, who at that time were being besieged by

\footnotetext{
${ }^{54}$ Ibid., 186.

${ }^{55}$ Ibid. , 189 .
} 
the Tatars. ${ }^{56}$ Instead, Humbert allowed himself to be caught up in Eastern political intrigue.

On the surface, clement seems to have acted contrary to ultimate success in nominating Humbert. Why appoint someone to such a monumental task, when that individual has trouble managing his own estate? clement VI wanted to be the unquestioned supervisor of this operation, only a man of Humbert's secondary status would accede completely to the Pope. Second, clement had only limited resources, and a scaled down passagium particulare was the only feasible way to proceed.

Humbert appeared at smyrna with grand plans and high hopes of success. He quickly realized, however, that his authority was challenge by various factions, principal among them were the Genoese and Venetians. Humbert came to see that the Smyrna campaign was merely a holding action the way it was being conducted. Lusting for adventure, Humbert became interested in the Byzantine and Catalan conflicts. Clement was informed that Humbert was straying from the mission. Not surprisingly, in 1346, Clement sent three strong letters to Humbert telling him to stay out of Catalan and Greek civil disputes. ${ }^{57}$ These letters had little discernable affect on Humbert. That same year, he began negotiating for the taking of chios. By establishing a base

${ }^{56}$ Housley, 34-35.

${ }^{57}$ Ibid., 255-56. 
on the island just off the Anatolian coast, he argued that Smyrna could better be supplied and defended. Clement acquiesced, and gave him permission to negotiate with the Greeks for a shared, political control arrangement. Clement eventually agreed to allow Humbert the right to negotiate with Anna of Savoy, the titular Byzantine empress and mother of the imperial claimant John V Palaeologus, concerning the reunion of Churches (a great interest of Clement's). As with everything that Humbert became involved with in the East, he met with failure. ${ }^{58}$

In the first case, the island of chios was retaken by Genoese forces before Humbert could move on it. The negotiations for the reunion of Churches fell through because Anna of Savoy had no real power base. John Cantacuzenus, an enemy of the western Church and imperial claimant, enjoyed the support of the Patriarch of Constantinople. He was also allied with Umur Pasher of Aydin. ${ }^{59}$ In 1347, when Cantacuzenus attained final victory, clement took up the matter of reunification with his old enemy.

History has not been kind to Humbert. He is criticized for not having the ability to consolidate his forces and deploy them with any innovation. He was called too "irresolute, pliable, and dilatory" to start another

${ }^{58}$ Ibid. , 255.

${ }^{59} \mathrm{Joseph}$ Gill, Byzantium and the Papacy: 1198-1400, (New Brunswick, N.J.: Rutgers University Press, 1979), 205. 
offensive inland. 60

The Smyrna offensive slowed considerably in 1346, and optimism for an expansion of operations waned. Humbert and Clement solemnly recognized the necessity for treaty with Umur Pashar to save what they had gained up to that date. In the summer of 1346 , Humbert began working on a treaty of nonaggression with the emir of Aydin. Work on the treaty was interrupted by Humbert's ignominious departure from Smyrna in the winter of 1347 . The early negotiation with Umur Pasher were unproductive because the emir recognized the precarious position of the tiny christian beachhead. With the death of Umur in 1348 , the Christians were able to produce a more favorable treaty, one which included the immediate cessation of piracy and the resumption of open trade. The occupation of Smyrna by Latin forces was perpetuated by several treaties with the emirs of Aydin, lasting until 1374.61

The Latin Naval League continued to serve effectively as a deterrent to piracy as long as it was fully funded and its leaders agreed on a single agenda. The league's finest hour occurred shortly after Humbert's departure, with a resounding victory in the sea battle of Imbros, at which heavy losses were inflicted on the less skilled Turks. subsequently, there were fewer sea battles, because the

$$
\begin{aligned}
& { }^{60} \text { Gay, } 71 . \\
& { }^{61} \text { Gay, } 74 .
\end{aligned}
$$


Turkish flotillas soon realized the disadvantage of engaging the more heavily armed Latins. While the league enjoyed full papal backing, it performed well in the East, but by the end of 1347, the league itself fell victim to unfavorable political and economic conditions in western Europe. ${ }^{62}$

Despite Clement VI efforts to forestall the league's demise, the papal galleys stopped reconnoitering in the summer of 1347. Clement refused to give up on his passagium particulare. As late as 1350 , we see him negotiating with the Venetians to renew the league against the Turks. These plans were dashed by the Veneto-Genoese War. Clement lost the help of the Hospitallers to the same dislocations that haunted the rest of Europe: plague, economic collapse, and internal problems. The Knights of st. John lost their leader, Hélion of Villeneuve, who had served Clement VI faithfully, to illness in 1350. The order of the Hospital also experienced a loss of over 360,000 florins to the collapse of Italian banking. ${ }^{63}$ Hugh of Cyprus, alone, could offer no resistance to the Turks. So by 1350 , the principal constituents of the smyrniote crusade were too enmeshed in their own internal problems to be of much help to clement.

\section{${ }^{62}$ Housley, 257.}

${ }^{63}$ Anthony Luttrel, "The Crusade in the Fourteenth Century," in Europe in the Late Middle Ages eds., J. R. Hale, J. R. L. Highfield, and Beryl Smalley (Evanston, Illinois: Northwestern University Press, 1965), 294. 
It has been calculated that the Latin League and Smyrna occupation cost Pope Clement over 200,000 florins. ${ }^{64}$ Recent investigations indicate that the amount was more likely closer to 140,000 florins. 65 Between 1343 and 1347 , Cameral officials paid out to the captain of the papal galleys, Martin Zaccaria, 33,546 florins. Clement sent an additional 110,800 florins to the Hospitallers for dispersement to the forces in the East between October, 1343 and september, 1346. These two amounts, garnered from Clement VI's registers, total 144,346. This corresponds closely to the theoretical amount that it would cost to outfit four galleys for three years and seven months. At 38,400 florins a year, multiplied by the duration of service, we arrive at a figure of 137,640 . By adding the cost of the captain's salary, approximately 1,800 florins a year, or 6,450 florins for three years and seven months, we arrive at 144,090 florins, a number close to the amount given in clement's registers. ${ }^{66}$ clement had to strain to collect this much money, and this is the reason why he promoted a smaller passagium particulare. The passagium generale of King Louis IX, between 1248-1254, cost in excess of $1,500,000$ livre of tours, a sum well out of the reach of

${ }^{64}$ Setton, Papacy and the Levant, 187.

${ }^{65}$ Housley, 301 .

${ }^{66}$ Ibid. , 301-02. 
any mid-fourteenth century monarch for such a project. ${ }^{67}$

Monies were increasingly hard to come by as the fourteenth century progressed for several reasons. War, famine and pestilence all played deciding roles in the dwindling money supply. The early part of the fourteenth century is replete with lamentations over the severity of famine. The horrible famine of 1317 had a rippling effect which reduced the work force through attrition, and spawned higher wages. The pandemic known as the Black Death hit the East in early 1347, and spread horror and misery. One source states that the plague was particularly virulent in the East, diminishing the population of Constantinople by more than half. ${ }^{68}$

Clement VI attempted to circumvent the difficulties caused by the collapse of Italian banking and the economic down turn caused by the declining Flemish cloth guilds in the mid-fourteenth century. The big monetary crash owed its genesis to the granting of questionable loans by Italian bankers to the French and English monarchs. When the validity of royal promises of repayment paled, and the banking house realized the depth of the impending loses, the money supply shrunk and the bottom fell out. In 1327, the Scali banking house folded. The Bonnacorci, the Usani, the Corsini banking houses failed in 1341. In 1343, the great

${ }^{67}$ Ibid., 163.

${ }^{68} \mathrm{Gi} 11,97$. 
Bardi, Peruzzi, and Acciajuoli banks crashed under the weight of forfeited loans. ${ }^{69}$ To attain the needed funds for the naval league and the occupation of Smyrna, Clement relied on smaller Italian banks. The financial records reveal that few loans exceeded a couple thousand florins. Whereas John XXII was able to extract larger loans less frequently, clement and the papal treasurer were forced to borrow much more frequently. ${ }^{70}$

The Smyrna crusade and the Holy League seem to justify the depiction of Pope Clement VI as a profligate, who squandered great sums of money on extravagant operations. It is an inescapable fact that he relied heavily on, and severely depleted the papal treasury endowed by his predecessors. When Clement VI became pope, the papal treasury boasted a reserve fund of over 1,117,000 florins; upon his death, there were only 311,115 florins in the treasury. ${ }^{71}$ Clement's holy war undoubtedly played a large part in its depletion. While a large proportion of the papal treasury went toward the crusade, the bulk of the outlays were expended on other projects, like the building of the papal palace, the acquisition of Avignon from Joanna

${ }^{69}$ Henri Pirenne, Economic and Social History of Medieval Europe (New York: Harcourt, Brace \& World, 1937), 192.

${ }^{10}$ Yves Renouard, Les Relations des Papes d'Avignon et des Compagnies Commerciales et Bancaires de 1316-1378 (Paris: Bibliotheque des Ecoles francaise d'Athenes et de Rome, 1941), 246-47.

${ }^{71}$ Mollat, 230. 
of Naples, the protracted imperial dispute with Lewis IV, and finally, large loans to the French king. 72

Clement VI was himself a very industrious and

innovative man when it came to fund raising. No pope of the Avignon period exploited the idea of ius spolia or the right of spoil, more than Clement VI. ${ }^{73}$ His promotion of the idea of the treasury of merit brought untold sums into the papal cache. ${ }^{74}$ Out of Clement's conception of the treasury of merit arose fictional characters like the pardoner in Chaucer's Canterbury Tales. ${ }^{75}$ He creatively initiated the idea of the fifty year Jubilee, based on Boniface VIII's formulation in 1300 , in which the sins of the faithful were remitted for the previous year if they made a pilgrimage to a Church of one of the Apostles. ${ }^{76}$ The invention of new economic streams were a mainstay to Clement's foreign policy.

Were Clement's crusading efforts rewarded, or did they sound the death knell for crusading in the Middle Ages? In the short term, his flotilla achieved its intended purpose

${ }^{72}$ Maurice Faucon, "Prets Fait aux Rois de France par Clement VI, Innocent VI, et le comte de Beaufort 1345-1360" (Paris: Bibliotheque de l'Ecole des chartes), 574.

${ }^{13}$ Philip E. Burnham, "The Patronage of Clement VI," History Today 37 (1978): 379 .

${ }^{14}$ Wood, Pontificate and Ideas, 33.

${ }^{75}$ Geoffrey Chaucer, The Canterbury Tales trans. Neville Coghill (Baltimore: Penguin Books, 1960), 257-73 passim.

${ }^{76}$ Wood, Pontificate and Ideas, 90. 
for as long as it endured: piracy was effectively checked, with the result being added security and increased trade. The long term evidence shows that Clement VI's efforts to promote crusading were no more enduring than earlier attempts had been. Islamic expansion was not checked. The recapture of Jerusalem remained an elusive objective. Unlike the earlier crusades, the crusade of 1340 left no visual reminders to indicate that there was a holy war in the $1340^{\prime} \mathrm{s}$.

There was a strong Christian presence in smyrna until 1402, when it fell to the determined Tamerlane. The strength of earlier treaties had rested on the tenet of mutual economic benefits, and had survived because of divided and incompetent Turkish rule. Tamerlane had little need of the former, and suffered not from the latter. As a result, the city was sacked in 1402 and the inhabitants of Smyrna were slaughtered.

The other arm of Clement VI's Eastern offensive, the Latin Naval League fared little better. Jules Gay states that the naval league was much like Latin armies. It was good for hard-hitting attacks of short duration, but it was too inefficient to be suitable for protracted war. ${ }^{77}$ In addition, the venetians are thought to have been exploiting economic strategies detrimental to the league's success,

\footnotetext{
${ }^{71}$ Gay, 87 .
} 
including a separate peace with the emir Umur. ${ }^{78}$ The Genoese hampered the operations of the naval league at every turn, as is evidenced by their treasonous recapture of Chios, despite Clement's commands to the opposite. Finally, the focus shifted westward from the Mamluks in Egypt and the Turks in Anatolia, to the protection of Latin Greece and the immediate Aegean sea lanes. In the uncertainty of the times, it is surprising that the league held together as long as it did.

In conclusion, the achievements of the smyrna crusade and the Latin league appear ephemeral when compared to the height of crusading activity in the twelfth and thirteenth centuries. The inglorious ending of Clement's crusade demonstrates that he was not fully informed, militarily, politically, and economically. While he pursued his mission with a resourcefulness and effort equal to that of Innocent II or Eugenius III, he was unable to elevate his ideal above the dislocation and disillusionment of his time. The most important ramification of clement's failed crusade was that it decreased, rather than increased, papal prestige. His involvement in crusading must be recognized for what it was -- an interlocking piece of a bigger plan, which was the revival of the papal monarchy.

${ }^{78}$ Housley, 204. 
CHAPTER IV

CLEMENT VI: PROTO-RENAISSANCE POPE

The standard account of the nineteenth century historian, Jakob Burckhardt implies that the Renaissance did not blossom in France until the fifteenth century. Many modern historians reject this narrow interpretation. Some push the date for the beginning of the Renaissance backward to the early fourteenth century with the cultural emergence of the Avignonese papacy. An increasing amount of evidence suggests that the rebirth of classical thought in France first took root in Avignon, during what Petrarch termed the "Babylonian Captivity." This revisionist view is still incomplete, but it does account for certain aspects which the narrower view either rejects or passes over. It is infinitely more difficult to pinpoint exactly when or under whose papacy it first flowered. I argue that the earliest date that these cultural and intellectual forces could have coalesced was in the early $1340^{\prime} \mathrm{s}$, around the munificent Pope Clement VI.

Many historians have associated the advent of humanistic studies in France to the cross-pollination of the late fifteenth and early sixteenth centuries, when King Charles VII of France sent troops into Italy. They contend that the splendor of the Italian culture and the ostentatious displays of prosperity enamored the hearts and 
captured the imaginations of the invading legions. The more limited historical view claims that the French then brought new Italian attitudes and ideas back to France with them. However, historians like Ernest Hatch Wilkins and Franco Simone point to the presence of Renaissance humanism in Avignon long before the Italian wars of the fifteenth and sixteenth centuries.

of all the Avignonese popes who preceded Clement VI, only John XXII showed much interest in classical learning. He was old and frugal when elected pope, but he remained industrious up to his death. John XXII worked to replace the intellectual and administrative machinery jettisoned by the papal court's move from Rome. It was John XXII who first summoned Petrarch to Avignon in 1326. The Papal library grew under his tutelage and incorporated many classical works, such as those of Pliny and Seneca. ${ }^{1}$ John XXII's pontificate, however, is highlighted by a preoccupation with typically scholastic arguments, specifically, his theories on Apostolic poverty and his curious assertions on the Beatific Vision. Finally, John XXII's ascetic lifestyle defies comparisons to the Renaissance popes of the fifteenth century.

The enduring legacy of the successor of John XXII, Pope Benedict XII, rests on his success in reforming the the larger religious orders. He labored to strengthen the

lFranco Simone, The French Renaissance (New York: Macmillian Co., 1961), 46 . 
position of the fugitive papacy by increasing the reserves in the treasury. He is not lauded by his contemporaries for his generosity or patronage. By any measure, Benedict XII was a product of the more conservative medieval tradition. So then the question falls, can Benedict's successor, Clement VI, be hailed the first Renaissance pope? What delineates or elevates his pontificate above the others, culturally, artistically, and intellectually.

First, it is folly to believe that so sudden a change could occur, as if, overnight the Middle Ages gave way to the Renaissance, or the events of clement VI's reign inspired a new way of thinking or behaving. History allows few sharp turns. His endorsement of classicism in the $1340^{\prime}$ 's did not mean the negation or renunciation of well over a thousand years of cultural heritage. Rather, the flowering of culture, art, and thought in Avignon can best be described as a synthesizing of the choice aspects of antiquity with the best examples of gothic.

The location and status of Avignon as a crossroads afforded a liberality of tastes and choices to its citizens. Its position in southern France on the Rhone River, close to the Mediterranean, spawned a wide and diverse population. Though dominated by France in politics, Avignon by its nature, was more Mediterranean in character. By midfourteenth century, it possessed a strong Italian flavor. Under the tutelage of the Angevins, it enjoyed greater freedoms than most cites its size in France. For these 
reasons, the papacy prospered there.

Avignon during the fourteenth century became the

cultural portal of Europe. Three forces were responsible for the magnetic appeal of Avignon to Italian scholars:

first, the availability of benefices and other

ecclesiastical salaries; second, the patronage of Italian

cardinals; and third, the exceptional reservoir of manuscripts in the Papal library. Italian cardinals from the Orsini, the Colonna, and Brancaccio families typically brought large retinues from their home cities or lands in Italy to maintain the culture and customs that they previously had enjoyed.

On their coattails came men like Petrarch, infected with a burning passion for classical literature. These men came from Italy to peruse the Papal library for original Roman and Greek writings. Other Italians came to Avignon to make a living and to help build a city fit for the papacy. Along with the artists and musicians came men trained in law, hoping to pick up any scraps that fell from the papal mensa -- benefices, provisions, and expectancies. Many talented Italians came to Avignon to escape the political and economic turmoil in their homeland. The wealth of opportunities in Avignon induced many Italian humanists to migrate to Provence. Franco simone asserts that,

The facts and reflections . . . are sufficient to show that from the middle of the fourteenth century there existed at Avignon a cultural centre whose vitality in men and works was in certain decades so great that it polarized all the new 
ideas reaching France from the civilization of Italy. . . we must entirely abandon Courjod's assertion that the contacts of French writers with Italy effected through the Avignon milieu before the sixfeenth century had no immediate or general effect.?

The argument for an Avignonese renascence suggests many avenues of proof, with the strongest proofs residing in the pontificate of clement VI. The principle humanistic attributes of Clement VI's reign were his interest in classical literature, his adaptation to the new forms of art coming out of Italy at the time, his acceptance of new forms of music, and his embracing of the early forms of political humanism. But like all history, the matter is not black and white. Pope Clement VI was imbued with characteristics which seem to hold him fast to medieval tradition and seemingly make any claims to an early coming of the Renaissance to France in his times, unwarranted.

To treat the above assertions more fully, three facets of the Renaissance question need to be addressed. Firstly, was Pierre Roger (Clement VI) a product of twelfth century renaissance or a forerunner of the Italian Renaissance? secondly, what does the early life of Pierre Roger tell us of the man's receptivity to humanism and innovation? Lastly, to what degree was he able grasp and understand this budding humanism of the mid-fourteenth century? By balancing his reluctance to discontinue the customs and traditions of the medieval church on one side, with the 
evidence that a bridge was indeed crossed and humanism embraced on the other, a more objective picture should emerge as to Clement VI's humanistic leanings.

A question that comes to the fore is why Clement's pontificate is considered a harbinger of the fifteenth century Italian Renaissance, rather than extension or outgrowth of the twelfth century renaissance as promoted by the likes of Charles Homer Haskins and Christopher Brooke? The problem is difficult to assess because the distinctions between the two renascences have been reduced to "sublime meaninglessness." ${ }^{3}$ Regardless, there are several differences which beg further examination. First, the Greek language was not widely known in the twelfth century in western Europe. Rather, Greek works were usually studied second hand, via Arab or Hebrew translations into Latin. This material was usually philosophical or scientific in nature. Thus, scholars of the twelfth century renaissance rarely embraced Greek imaginative literature, such as Homer's works, which were a central theme in the Italian Renaissance. Christopher Brooke notes that the twelfth century was a time of "real sympathy and insight into classical Latin literature; but also an astonishing wealth of ignorance." With the Italian Renaissance, we witness a

${ }^{3}$ Richard W. Southern, "The Place of England in the Twelfth Century Renaissance," History 65 (1960): 203.

"Christopher Brooke, The Twelfth Century Renaissance (New York: Harcourt, Brace \& World, 1970), 10. 
stronger commitment to the primary text and more informed interpretation. In deed and in act, clement demonstrates a greater propinquity to the Italian model than the general tweleth century model.

If indeed, Clement VI was the first Renaissance pope, the pulse of humanism should be palpable in the surviving documents and activities of his youth. Pierre Roger was born in 1290 or 1291 , probably at Maumont in the region of Limoges, France. His father was seigneur of Maumont, one of the lowest rungs of petty nobility. Being the second son, Roger was sent off to the Benedictine monastery of ChaiseDieu. There, he was indoctrinated into the rites and simple life of the order. At Chaise-Dieu, his intellectual receptivity and oratorical ability became evident. The Abbot of Chaise-Dieu recognized "not only his marvelous memory and clear judgment, but his wonderful comprehension." Roger was at the monastery for only a short time, allowing little opportunity for the residue of simple piety to build up. He was sent off to the University of Paris to be formally trained in theology.

Roger arrived in Paris in 1307 to begin work on a degree in theology. He was only fifteen when he arrived in Paris, where he probably entered the College of Narbonne as

${ }^{5}$ John E. Wrigley, "Clement VI before His Pontificate: The Early Life of Pierre Roger, 1290/91-1342," The Catholic Historical Review 56 (October, 1970), 437. 
a graduate grammarian. ${ }^{6}$ Little is known of the intervening years between 1307 and 1322 other than the fact that he was given the benefice of the small priory of st. Pantaleon in Limoges by the abbot of Chaise-Dieu to support him financially. While in Paris, he acquired a reputation as a fine scholar, and an even better orator. Upon completing his bachelor's degree, he lectured on the scripture and the Sentences of Peter Lombard. He then began work on his doctorate. Roger's talent was so striking that it attracted the favor of the king of France. King Charles IV asked Pope John XXII to intervene on Roger's behalf with the chancellor of the University in order to grant Pierre Roger his doctorate earlier than was normal.?

Pierre Roger was a strong proponent of Aquinian theology. John Wrigley comments that Roger considered Aquinas the greatest of all philosophers and theologians. Roger could often be found, in this period, debating the merits or utility of some Aquinian thesis. It is also intriguing that Roger received his doctorate only weeks after Aquinas was canonized. He was named professor and eventually provost of the sorbonne. ${ }^{9}$ His exceptional academic achievements in theology are indicative of his

\footnotetext{
${ }^{6}$ Ibid.

TIbid. , 439 .

${ }^{8}$ Ibid. , 440 .

${ }^{9}$ Ibid. , 440-41.
} 
genius, but he was equally talented in the secular arena. Upon completion of his academic requirements, Pierre Roger found his talents in demand. The oratorical abilities and quick wit which elevated him above his class, also attracted the attention of the pope in Avignon, the powerful Cardinal Pierre de Mortemart, and particularly to the royal court of France. ${ }^{10}$ He was still a young man when the king of France and the Pope began using him as an envoy. Charles IV of France employed Roger as a representative in missions between France and England in hopes of averting war. In addition to his diplomatic work, he was also retained by the king as a tutor for the French princes Philip VI and Jean II. II It was there that he first met and taught charles IV of Luxembourg, whom Roger, as Clement VI, later helped become the Holy Roman Emperor.

Royal and papal connections assisted Roger's climb up the ecclesiastical ladder. He was made prior of the monastery at st. Pantaleon in 1316, and then elevated to abbatial office at the great monastery at Fecamp in Normandy in 1326. This appointment made him a vassal of Edward II of England. It also opened important links with people in England, and this bond aided future negotiations.

After continued successes in the diplomatic arenas of France and England, he increasingly garnered the respect and

$$
\begin{aligned}
& { }^{10} \text { Ibid., 443-44. } \\
& { }^{11} \text { Ibid., 461-66. }
\end{aligned}
$$


loyalty of the French king, Philip VI. In the next three years, he profited from his efforts by receiving the endowments of three of the larger bishoprics in France. In 1328 he became bishop of Arras, in 1329, archbishop of Sens, and finally, in 1330, archbishop of Rouen.

Even with the greater demands placed on his time by these promotions, Roger rarely left Paris or the king's company to supervise his benefices. The three later benefices were wealthy, especially Rouen, and it was with some regret that he gave these up for the red hat of the cardinalate. He was able to live comfortably, however, with financial help from the French king. ${ }^{12}$ The shadow cast by Pierre Roger in the $1330^{\prime} \mathrm{s}$ was a long one, and more resembled that of a prince than a bishop.

The extant writings of Pierre Roger reveal a man who deeply loved classical philosophy. He was well versed in Aristotle, primarily as interpreted by st. Thomas Aquinas. This was one of the reasons why he was favored by the conservative Pope John XXII. John XXII had young Pierre Roger debate with the Franciscan, Francois de Meyronnes over the nature of the Trinity. ${ }^{13}$ Roger held the orthodox Aquinian view of indivisibility of the Trinity. Meyronnes argued for the scotistic view of formal distinctions. The Franciscan scotistic view was the more in vogue opinion in

12 Ibid., 471 .

${ }^{13}$ Diana Wood, Clement VI: The Pontificate and Ideas of an Avignon Pope (Cambridge: Cambridge University Press, 1989), 8. 
Paris at the time. This confrontation over the nature of the Trinity helps to demonstrate that while Pierre Roger was liberal in temporal things, he usually remained traditional and conservative in theological matters. ${ }^{14}$

The strongest piece of evidence of Roger's affinity to humanistic studies can be found in the vatican document Borghese 247. Anneliese Maier offers the opinion that the document recommends him as a "Vorlaufer der grossen Renaissancepapste. "15 Borghese 247 contains material found in many "commonplace books of the Renaissance."16 Pierre Roger seems to have aimlessly copied anything that interested him. In addition to the many theological tracts that he transcribed, there are several folios of material treating such diverse subjects as astrology, classical literature, and medicine.

The topic of astrology figures prominently in Borghese 247. Astrology figured as prominently in the Middle Ages as it did in the Renaissance, but this pseudo-science seemed to find renewed vigor in the fourteenth century. Roger exhibited great interest in the stars. J.H. Plumb relates that in the Italian Renaissance, the stars were studied

${ }^{14}$ I bid.

${ }^{15}$ Anneliese Maier, "Der literarische Nachlass des Petrus Rogerii," Ausgehendes Mittelalter gessammelte Aufsatze zur Geistesgeschichte des 14. Jahrhunderts, vol 2, (Rome, 1964), 309 .

${ }^{16}$ Wood, 65 . 
before any important diplomatic moves or decisions were made. The Renaissance popes, Julius II and Paul III, guided their decrees only after an auspicious recommendation by the stars. 17 Jakob Burckhardt observed despairingly that astrology diverted precious imagination away from classical literature and philosophy. He cited Petrarch's frequent disparaging words on the subject. 18

Borghese 247 is replete with astrological observations. In folios 19r-20v, Roger treats the birth of christ and the zodiac. In folio $21 \mathrm{v}$, he comments on circulus vitae et mortis, specifically, the celestial bodies and their effects on the course of human events. Owing to the fact that the study of the stars was not as scientifically defined in Roger's time, it is difficult sometimes to recognize where astrology leaves off and astronomy begins. There are references, however, that note the position of stars and constellations in Borghese 247. His scientific interest in the predictability of the stars suggests a curiosity more in tune with astronomy. In addition to his astrological discourses, there are related passages on chiromancy or palmistry. Roger's interest in the black arts are represented by several tracts in Borghese 247. These tracts probably represent a general interest of Roger's in the

${ }^{17} \mathrm{~J}$. H. Pl umb, The Italian Renaissance (New York: Harper \& Row, 1961), 22.

${ }^{18} \mathrm{Jakob}$ Burckhardt, The Civilization of the Renaissance in Italy (New York: Random House, 1954), 288-89. 
subject, which coincided with a common preoccupation of French society with magic. ${ }^{19}$

of all the authors of the Roman classics translated and praised by Renaissance humanist scholars, few received the attention lavished upon Cicero. It only seems fitting that we find tracts from Cicero figuring prominently in a document transposed by one of the greatest orators of his day. Roger dedicated several lines of commentary to Cicero's ethics. There is a transcription of part of Aristotle's Metaphysics, and the table of contents of his Physics.

Pierre Roger, the exegete, recognized the importance of understanding the original sources employed by Thomas Aquinas. 20 Faced with constant petitions to debate with the foes of st. Thomas, Roger's comprehension of Aristotle's teachings were especially astute. Like most scholastics, Roger had to rely on second hand translations of the originals. In this area, his interests parallel more the twelfth century humanists. The passages of Borghese 247 which define his tastes most clearly are those that focus on his commitment to the classics, a devotion which never waned.

There is a passage in Borghese 247 which describes the

\footnotetext{
${ }^{19}$ Maier, 309-10.

${ }^{20}$ Ibid. , 310 .
} 
common wisdom of the day in the field of medicine. ${ }^{21}$

Roger's early interest in medicine undoubtedly paid dividends during the scourge of the Black Death. I believe that he was interested in the biological sciences for the simple reason that he himself suffered from poor health. His frail health is corroborated by a later letter to him from Petrarch. ${ }^{22}$

Finally, we can draw one last inference of Roger's humanistic leanings from Borghese 247. A hallmark of the Italian Renaissance was proficiency in the languages of the classical world so as to allow first hand observations and analysis. Latin was commonly known in the fourteenth century, but its elder kin, Hebrew and Greek were not. In Borghese 247 , the Hebrew alphabet was transcribed, which indicates that he wished to learn the language. Like Petrarch in respect to the Greek language, Roger was never able to completely master the Hebrew language. ${ }^{23}$ The effort demonstrates, to some degree, the intensity of his passion for things classical.

The Borghese document does not clearly show any rigid delineation between medieval and Renaissance modes of thought. The document reflects the interests of a young

${ }^{21}$ Ibid. , 309.

${ }^{22}$ John E. Wrigley, "A Papal secret Known to Petrarch," Journal of Medieaval Studies vol. 39, no. 4, (October 1964): 621-22.

${ }^{23}$ Wood, $65-66$. 
man, still evolving, still maturing. Nevertheless, Borghese 247 does provide an excellent bit of evidence that the spirit of humanism was not unknown to Pierre Roger.

A final piece of evidence from Roger's formative years which suggests a tendency toward humanism can be found in his love of books. He rarely went anywhere without the comfort of a book or two. Richard of Bury, an English envoy, who conferred with Roger on several missions from Edward III, commented on Pierre Roger and his love for books, a love which they shared in common. Richard writes,

Moreover in performing frequent embassies for the same illustrious Prince of everlasting memory, we [Bury and Roger] were sent on tedious embassies in time of peril, now to the Roman see, now to the Court of France, and now to the divers kingdoms of the world, yet bearing with us everywhere that love of books which.. . sweetened the bitterness of all our travel. This, after the perplexing intricacies and troublesome difficulties of cases and almost interminable labyrinths of public affairs, opened to us for a little, the balminess of a gentle atmosphere to breathe. ${ }^{24}$

The account of the conversations between these two men indicates that their like interests were not limited to theology or diplomacy. Opportunities must have arose when they discussed subjects that were far afield of these topics. These two bibliophiles must have shared reflections on classical literature and philosophy. This is manifested by the fact that Roger harbored a great love for books, secular as well as theological.

${ }^{24} \mathrm{John}$ E. Wrigley, "Early Life of Pierre Roger," 465. 
The diplomatic skill of Pierre Roger and Richard of Bury foreshadowed in some ways the Italian advancement in diplomacy of the fifteenth century. Diplomacy, in the sense that we know it, was, after all, a bench mark of the fifteenth century Renaissance movement. The competing factions in Italy relied on diplomatic missions to deal with the ever changing political panorama. The competing natures of these various small kingdoms demanded that envoys be given greater latitude in their negotiations. In many ways, the French and English conflict in the fourteenth century was a macro example of the Italian political situation, especially in the lust for power and territory.

Out of the milieu of the Hundred Years War, Pierre Roger emerged as a predecessor to the evolution of later Italian diplomatic development. Roger possessed the two particular attributes defined by the quintessential diplomat of the Renaissance: self-confidence and a concept of realpolitik. Examples of his political practicality were manifested in his dealings with England for the French king. His political realism was also revealed by his diplomatic stalling, which prevented a confrontation between Pope John XXII and the French king over the Beatific Vision. ${ }^{25}$

The differences between fifteenth century Italian diplomacy and Roger's early fourteenth century example are

${ }^{25}$ Kerry Spiers, "Lectures on the Avignonese Papacy," Lecture presented at Gottschalk Hall in Louisville on 29 October 1991. 
two. First, Churchmen like Roger increasingly took backseat roles to educated laymen in diplomatic matters. Next, a hallmark of Roger's diplomacy was his willingness to apply theoretical or outdated claims as justification in his diplomatic dealings. He only employed realpolitik as a last resort. This is evidenced by his papal relationship with Lewis IV of Bavaria and Charles IV of Luxembourg. When all theoretical claims of Papal authority failed to move Lewis IV, Clement VI simply outflanked him by promoting a rival imperial claimant, Charles of Moravia.

Another example of Clement's realpolitik occurred in the Plague years. European Jewry was accused of starting the Plague by poisoning the wells of Christians. Clement VI realized the futility of demanding that the Jews be left in peace (as previous popes had done to little avail), and so he chose to invite Jews to Avignon. This was done for two reasons: firstly, he could personally ensure their protection, and secondly, he recognized the wealth that these Jews would bring with them. ${ }^{26}$

Pope Clement's dealings with Giovanni Visconti of Milan are illustrative of his idea of diplomacy. By playing the balance of forces against each other in Italy, he was able to maintain a semblance of peace during his reign. Clement VI was not above taking the position, if you can not

${ }^{26}$ E. A. Synan, The Popes and the Jews in the Middle Ages (New York: Harper \& Row Publishers, 1965), 133. 
beat them, then join them. ${ }^{27}$ The skills that marked Pierre Roger for greatness -- intelligence, oratorical ability and wit -- were the especially prized attributes of a Renaissance diplomat.

With the election of Pierre Roger to the highest ecclesiastical office, more solid examples of his humanistic leanings surfaced. He was very magnanimous in his treatment of art and architecture, courtly life, science, and music. Concurrent with his election was a general growth in the appreciation of Italian art and culture. Therefore, we see an increased number of Italians being called to Avignon. This is not to say that he was any less French in his taste, but his new office allowed him to taste the fruit of many trees, and Avignon provided a veritable grove.

When Clement VI purchased the city of Avignon from Joanna of Naples in 1348, he was simply making manifest that the impetus to return to Rome had waned. Clement VI, unlike Benedict XII and John XXII, had no intention whatsoever of returning to Rome. In this respect, he was the most French of the Avignonese popes. The city boasted a fortuitous location on the Rhone River, a stable economy, and a fairly placid political situation. Clement VI shrugged off the difficulties of abandoning the Holy see in Rome with terse assertions about his power coming not from Rome, but from

${ }^{27}$ Guil 1 aume Mollat, The Popes at Avignon: $1305-1378$ trans. Janet Love (London: Thomas Nelson and Sons, 1949), 124-25. 
God: ubi papa, ibi Roma. ${ }^{28}$ To confine papal auctoritas to a single city was to limit its catholic dimension. He never said outright that he would not return to Rome; on the contrary, often he detailed his longing to return. He closed one of his sermons, given to an embassy from Rome, "desidero videre vos." 29 His actions, however, proved otherwise. His goal was to build a city to rival Rome. The sense of permanence built into the papal palace during Clement VI's reign provides a visual reminder of the strength of his commitment to Avignon.

An examination of Clement VI's courtly life exposes several interesting points. The first thing that struck most visitors to Avignon was the circus atmosphere surrounding the Papal palace. Unlike the stately, official atmosphere of the see in Rome, the palace at Avignon was home to a large contingent of laity, including many of clement VI's family. In addition to all the children and women scurrying through the hallways on any given day, the palace was full of foreign visitors seeking appointments, provisions, and benefices. The palace was always busy with the activity of artisans. Mixed amongst these throngs were artists, writers, poets, and jongleurs. Antoine Pelissier

${ }^{28}$ Conrad of Megenberg, Yconomica, iii, 3, chap. 13, 404, in wood, 46 .

${ }^{29} \mathrm{Clement}$ VI, "Sermon 14," Bibliotheque de Ste. Genevieve 240, fol. 149v, in Wood, 43 . 
states,

Clement VI avait attire a sa cour les plus beaux esprits de 1 'epoque : hommes de lettres, poetes, peintres, sculpteurs, architectes, medecine, physiciens, astronomes venaient en Avignon de France, d'Italie, d'Espagne, d'Allemagne, et la Pape fournissajt a tous les possibilites d'exercer leur activite. 30

Interestingly, Clement VI kept a small menagerie at the palace, including a lion and bear. Petrarch proudly recounted that his dog fared quite well against Clement's 1 ion on one visit. 31 In many ways, clement VI's court was more reminiscent of the court of a monarch, than that of the vicar of st. Peter. The secular never before had embraced the spiritual as tightly as it did during clement VI's pontificate.

Three physical features existed in Avignon during Clement VI's reign which indicate that there was a renascence or rebirth. They lie in the art and the architecture of the Papal palace, and in the holdings of the Papal library.

Firstly, in the areas of art and architecture, it must be stated that pope Clement VI was most accustomed to and comfortable with the Gothic variety. Many of the great Gothic edifices of France were barely two hundred years old, and the impulse of Gothic lines and symmetry was still very

\footnotetext{
${ }^{30}$ Antoine Pelissier, clement VI: le Magnifigue (Brive, France: Imprimerie Lachaise, 1950), 43.

${ }^{31}$ Philip E. Burnham, "The Patronage of Clement VI," History Today 37 (1978): 378 .
} 
strong. In architecture, the Gothic model was peerless and it dominated the European scene in the fourteenth century.

The strong Italian characteristics of the papacy were not lost with the move to Avignon. In fact, the Italian influence was inseparable from the papacy. When Pope Clement $V$ settled in Avignon in 1309, many Italians understandably followed, including artists. The alternative styles of Cimabue and Giotto, while offering fullness and truer representation, were still in their exploratory stage. The beauty of their work, however, did not escape papal recognition. In a commentary on Dante's Purgatory, Vasari made an allusion to Giotto and his interests in Avignon. Giotto was and is the greatest of painters and also comes from the city of Florence; and his work at Rome, Naples Avignon, Florence, and Padua bears this out.

Vasari goes on to say,

Shortly afterwards Benedict XI died, Clement $V$ was declared Pope in Perugia and Giotto was forced to go and work for him in Avignon where he established his court. He executed a large number of very fine panel pictures and frescoes in Avignon and elsewhere in France, giving greagt satisfaction to the Pope and all his court. 33

So elements of the early Renaissance were present in Avignon from the very beginning of the papacy's stay there. The Papal palace was begun by Benedict XII in the first months of his pontificate. Through the insistence of the

${ }^{32}$ Giorgio Vasari, Lives of the Artists trans. George Bull (New York: Penguin Books, 1965), 55.

${ }^{33}$ I bid. , 67 . 
French king and owing to the uproarious conditions in Rome, Benedict XII decided to build a fortress in Avignon to house the papacy in comfort and safety. Originally, it was not very ornate; form followed function that being to safeguard the parsimonious, Cistercian Pope. At the same time, however, he refurbished the Church of st. Peter in Rome, leaving open (at least superficially) the possibility of returning to Rome. This explains in part why Benedict XII did not build a spacious and decorative abode befitting the papacy in Avignon. ${ }^{34}$

The election of clement VI upon Benedict XII's death ushered in a new era of sumptuous buildings. Clement VI's tastes were more ostentatious and his demeanor more tolerant. He proudly proclaimed, "My predecessors did not know how to be popes." 35 A chronicler of Clement VI, Peter Herenthals states, that Clement's court "was held in most sumptuous state and with many parades and games." 36 The banquets he held were unmatched in Europe. Clement VI believed that none of his subjects should leave his presence unsatisfied. ${ }^{37}$

Clement VI continued work on the palace, employing

$$
\begin{aligned}
& { }^{34} \text { Mollat, } 318 . \\
& { }^{35} \text { Mollat, } 38 . \\
& { }^{36} \text { Peter of Herenthals, vita clementis VI from s. }
\end{aligned}
$$
Baluzius, Vitae Paparum Avenionensium ed. Guillaume Mollat (Paris: 1914-1927), 508-09.

${ }^{37}$ Burnham, 370 . 
many laborers from France and Italy. News of Clement's generosity found its way around, and it is not surprising to find accounts like the one of two carpenters in Florence in 1344, who corresponded with a friend in Avignon inquiring about work, because "the condition of the artisans and lower classes in Florence today is miserable, for they can earn nothing."38 The expansion of the Papal palace in Avignon nearly doubled the size of Benedict's fortress. Starting with the exterior, the famous Parisian architect, Jean de Louvre expanded along the fortress lines of the pre-existing structure, but the austere Roman characteristics surrendered to Gothic elements, like crocketed spires and repeating Gothic arches. Clement VI desired to have a palace equalling those of the king of France. ${ }^{39}$

The interior of the palace conveys the sense of a Renaissance awakening. Those elements which define the term "Renaissance art" -- a genuine representation of natural objects, a preference for profane or natural subject matter and lastly, the use of perspective -- were all included in the construction and paintings of the palace. Fine examples of these techniques can still be found in the Papal bedroom. The frescoes covering most of the bedroom walls were originally attributed to clement VI, but are now credited to Benedict XII. There are two representations of bird cages

${ }^{38}$ Gene A. Brucker, Renaissance Florence (Berkeley, California: University of California Press, 1969), 26.

${ }^{39}$ Burnham, 375 . 
on one wall in the bedroom chamber, drawn in perspective. They are stylistically different from the frescoes covering the rest of the room, and it is suggested that they may be the work of Matteo Giovannetti, the famous Italian artist and client of clement VI. ${ }^{40}$ The room which best displays Clement's love of the profane is the Chambre du cerf (Chamber of the Deer). The walls are decorated with images depicting such worldly subjects as "falconry, fishing, staghunting, . . and bird catching."ll The palace artists and artisans were also hired to do restorative work on the papal retreat across the Rhone river in Villeneuve and at the Benedictine monastery, Chaise-Dieu. ${ }^{42}$ so as not to over emphasize the Italian elements -- it must be acknowledged that clement VI wanted to surround himself with the best of everything - the artists were chosen as much for their superior skill as their style.

Humanists scholars were drawn to Avignon because of its voluminous and comprehensive Papal library. In the area of book collecting, two Avignon popes stand out, John XXII and clement VI. John XXII's initial efforts brought several works of classical literature into the collection. During the spendthrift tenure of $\mathrm{Clement} V I$, however, the enterprise of collecting books grew unchecked. Clement

\footnotetext{
${ }^{40}$ Wood, 59.

41 Ibid.

42 Ibid.
} 
added over one thousand books to the library through ius spolia, the right of spoil, alone. ${ }^{13}$ He added many more manuscripts through the largess of the Papal treasury.

Clement VI collected both profane and religious works. The first book that he ever bought was a commentary on Cicero in $1312 .^{44}$ Early in his reign, Clement VI asked the Italian, Luca Manelli, to compose a critique of the stoic Seneca. ${ }^{45}$ The Papal library boasted one of the best collections of classical literature in Europe, and this was one reason for Petrarch's long stays in Avignon. Clement VI solicited Petrarch to acquire as many works on Cicero as he could find. ${ }^{46}$ clement VI's thirst for classical literature was unquenchable.

With Clement VI's help, the Papal library in Avignon became the largest in Europe. ${ }^{47}$ It took 184 carpenter days in the reign of Innocent VI to provide enough shelves for the books acquired by his predecessor. ${ }^{48}$ Clement VI's interests in classical literature, combined with his dependence on Italian scholarship, establishes better than

\footnotetext{
${ }^{43}$ Burnham, 379.

${ }^{44}$ Wood, $67-68$.

${ }^{45}$ Wood, 68 .

${ }^{46}$ Burnham, 379 .

${ }^{47}$ F. Ehrle, Historia Bibliothecae Romanorum Ponitificum (Rome, 1890), 584-85.

${ }^{48}$ Burnham, 379.
} 
any other piece of evidence his place among the Renaissance popes of the fifteenth and sixteenth centuries.

In the fields of art, architecture, and literature cogent arguments for a classical renascence in Clement VI's reign can be made. His tastes in music, however, tended to favor more traditional medieval strains. The Papal records abound with evidence of Clement VI's love of music. They are replete with listings of musicians hired by the Avignonese pope. ${ }^{49}$ His musicians were hired for one of two reasons: either to sing the Mass and perform other religious ceremonies, or to sing or play at banquets on secular occasions, a common occurrence during clement VI's pontificate. These musicians were often employed as minor clerics.

It is commonly accepted that a renascence in music occurred in Italy late in the fifteenth and throughout the sixteenth century. The crowning efforts of this movement are found in the works of luminaries like Jacquin de Pres and Palestrina. Jakob Burckhardt characterized Renaissance music as having multiple, often exotic instruments playing in concert. It favored one singer, "for a single voice is heard, enjoyed, and judged far better." ${ }^{50}$ The opposite direction was taken in fourteenth century France by $\mathrm{Clement}$ VI .

${ }^{49}$ Andrew Tomasello, Music and Ritual at Papal Avignon: 1309-1403 (Ann Arbor, Michigan: UMI Research Press, 1983), 13.

${ }^{50}$ Burckhardt, 291 . 
In northern Europe, the Flemish school of music was more appreciated and patronized. It was lauded for its complexity and experimentation. The Flemish school was especially favored in France, and in particular in the royal court. While stationed at the French court of King Charles IV and Philip VI, the future pope, Clement VI, developed an appreciation for this musical style. Popular at this time was the variation known as ars nova. Pope John XXII had condemned its use in religious ceremonies, complaining that it used too many instruments and mirrored secular music too closely. 51

When the Pope's tiara was passed upon the death of Benedict XII, Clement VI quickly tried to acquire the services of those musicians whom he favored most. Many famous musicians found prominence in Avignon, including Philippe de Vitry, the originator of the ars nova, Jehan de Murs, and Levi ben Gershon. The Avignon style of music was born out of the efforts of these and other Avignonese musicians, who experimented with polyphony, pitch and rhythm. ${ }^{52}$ The papal records of Avignon are the first to mention "the singing of polyphonic mass ordinaries and to the use of the organ in the chapel of the pope." 53 In the fourteenth century, the Flemish school was considered more

\footnotetext{
51 Tomasel10, 9.

${ }^{52}$ Ibid. , 14-16.

${ }^{53}$ Ibid. , 122 .
} 
advanced than the Italian. In clement VI's pursuit of the best that Europe had to offer, it was logical for him to promote the French style, which was closer to his tastes and culture. Thus, in this area, an Italian Renaissance nexus does not exist.

The strongest causal link to a rebirth of classical appreciation and learning in Clement VI's reign is manifested in the presence of Italian humanists. These humanists lauded the reanimation of the great antique works, and commonly placed only secondary emphasis on works of the Middle Ages. The renascence of classical philosophy, literature, poetry, and science were seen, rather romantically, by the humanists as tangible portals to the past, ones which could improve the quality of the present. These men were on the cutting edge, and it was for this reason that Clement VI welcomed them into his company. Undoubtedly the greatest humanist talent of the age was Francesco Petrarch. Born in 1304 in Arezzo, Petrarch was the son of a notary, who had been outlawed in Florence and had moved to southern France. He was trained in law at Montpellier, and in 1320, moved to Bologna to advance his study of law. By 1326, however, he had given up law and made his way to Avignon, auspiciously to take advantage of the opportunities there and to plumb the rich Papal library. In 1330, it is thought that he received minor orders, though 
this has been questioned. ${ }^{54}$ The distribution of benefices to laymen was often practiced during the Avignonese exile. If Petrarch received minor orders, it was to increase his chances of receiving richer benefices.

Petrarch's writings reveal that he was very cynical about the nature and the course of the Avignonese Church. He perceived a deviation from the true mission of the early Church. Championing the view of st. Augustine, he railed against the Church as being too occupied with the earthly kingdom. Though he ranted and raved about the misdirected Church, he was not above profiting from its "abuses."55 Petrarch was in the hire of Giovanni Colonna when Pierre Roger became pope. Clement VI's conspicuous generosity offered hope to any budding talent who lusted for wealth, and the leisure to enjoy it. So, Petrarch cultivated clement's friendship. Correspondence between the two indicates, at the least, a cursory friendship. Petrarch's letters to him touch on many subjects: some inquire into his health, others give advice, and still others ask for favors. Between the years 1342 and 1352 , he spent around four years in Avignon. ${ }^{56}$ Petrarch held no

${ }^{54}$ Ernest H. Wilkins, studies in the Life and Works of Petrarch (Cambridge, Mass.: Crimson Printing Company, 1955), 3 .

${ }^{55}$ John E. Wrigley, "A rehabilitation of Clement VI," Archivum Historiae Pontificae 3 (1965): 136-37.

${ }^{56}$ Ibid., ix. 
less than five appointments under Clement VI. ${ }^{57}$

It was initially through Petrarch's influence that Cola di Rienzo acquired papal favor. Rienzo led a popular front that challenged the political status quo in Rome. Before long, he had alienated the ruling families. His struggle against the strong-arm Colonna and orsini families in Rome won him little favor in the higher echelons of that society. One of the more powerful men in Clement VI's college was a member of the Roman patrician class, Cardinal Giovanni Colonna, who had been a benefactor of Petrarch. This set up a dynamic of conflict which affected any party that had a stake in the stability of Rome. Clement VI became intrigued by this upstart Roman patriot.

In Petrarch's letters to Rienzo, the common elements were their mutual love of the classics and the desire to see again the glory that was Rome. ${ }^{58}$ How much clement VI shared their zeal is particularly questionable. He recognized Cola di Rienzo as a means to an end, that being a stable Rome, where he would have a greater share in the power. In a more personal light, the brash ideas of the Roman patriot Rienzo may have enchanted $C l$ ement $V I$ in the same fashion that it captivated Petrarch. In the face of Cardinal Giovanni Colonna's opposition to Rienzo's putsch,

${ }^{57}$ Ibid., 8-14.

${ }^{58}$ Francesco Petrarch, Rerum Familiarium Libri I-VIII trans. Aldo S. Bernardo (Albany, N.Y.: State University of New York Press, 1975), 349-52. 
it is intriguing that clement VI promoted Rienzo as notary of the civic camera of Rome. ${ }^{59}$

clement VI eventually recalled his support for the whole plan to make Rome a republic again. Cola di Rienzo lost touch with his original philanthropic ideals and fell victim to his own ego. How much Clement VI was exercising political savvy or just waxing romantically about the prospects of Rienzo's adventure can never be fully known. clement VI remained available and open to Petrarch's lobbying and fascinated by this early manifestation of classical humanism.

The final area in which the humanistic perspective held sway during clement VI's papacy occurred in the sciences, especially in medicine and astronomy. Clement VI patronized physicians, astronomers, inventors, and mathematicians. As Vatican Borghese 247 ably illustrates, he held a varied interest in the natural sciences most of his life. As with every other interest, clement VI sought out the best and the brightest in the field. Few popes, or princes for that matter, could claim a more able or analytical entourage of scientific advisers than those assembled by clement VI during his ten year rule.

The field of medicine witnessed remarkable advancements during in Clement VI's pontificate, thanks mainly to the Black Death. With half the population of

${ }^{59}$ Marlo E. Cozensa, Petrarch: The Revolution of Cola di Rienzo (Ithaca, New York: Ithaca Press, 1986), 13. 
Avignon succumbing to this tortuous malady, Clement VI had to pool all of his resources for defense. ${ }^{60}$ There were several attempts to understand the origins of this pandemic. One avenue of inquiry was in the field of astrology. Jehan de Murs and Levi ben Gershon were employed to explain the genesis of the Black Death using astrological observations..$^{61}$ Another avenue of exploration promoted by the pope was in the anatomical sciences. These dire times required desperate measures.

The famous French physician Guy de Chauliac was invited to Avignon during this period as a personal physician. He was known primarily for his surgical abilities. ${ }^{62}$ He also was ahead of his time in pathology. He criticized his medieval medical forerunners who "followed one another just like cranes." 63 The results of his observations in bubonic pathology are remarkably close to a germ theory. ${ }^{64}$ Clement VI allowed the dissection of cadavers by Chauliac and his colleagues to determine the cause of this pandemic. Clement's encouragement ran contrary to the earlier decree of Boniface VIII, Detestantae

${ }^{60}$ Wood, 66.

${ }^{61}$ Tomasel10, 15-16.

${ }^{62}$ Lynn Thordike, Science and Thought in the Fifteenth Century (New York: Hafner Publishing, 1963), 102.

$$
\begin{aligned}
& { }^{63} \text { Ibid., } 94 . \\
& { }^{64} \text { Ibid. , 4-5. }
\end{aligned}
$$


feritatis abusum, which stressed the idea of bodily resurrection. As Diana Wood points out, Clement VI's acceptance of current medical approaches contradicted the doctrinal belief of "suffering as the will of God."65 Clement VI did not believe suffering to be inevitable or unavoidable.

In a letter to clement VI from 1351, Petrarch had a word to say about the efficacy of medicine in his day: "They learn their trade at the expense of our lives, and death is the result of their experiments. Only a physician may kill with impunity." He went on to prescribe the lesson of the Roman Republic, which survived and flourished over six hundred years without the benefit of physicians. ${ }^{66}$ His remarks were spawned out of concern for a malady from which Clement VI personally suffered. It appears as though Clement VI had some form of encephalitis, manifested near the beginning of his reign and the probable cause of his death. It was described to the king of France by one of Clement VI's secretaries as a "fever with a rheum descending from his head to his jaw."67 so clement VI's interests in medicine were more than impersonal, philanthropic dabbling. This fact helps account for his vast outlays of money for

${ }^{65}$ Wood, 67.

${ }^{66}$ Wrigley, "A Papal Secret," 624-25.

${ }^{67}$ Eugene Deprez, J. Glenison, and Guillaume Mollat, ed., Clement VI: Lettres Closes, Patentes, et curiales se rapportant a la France (1901-61), vol. 1, no. 1671, cols 514515. 
experimentation and subsequent medical advances.

other scientific developments were made in clement VI's reign in the field of astronomy. In 1342 , at the request of $\mathrm{Clement} V I$, Peter of Alexandria translated an astronomical passage called "The Instrument That Reveals Secrets." It was an excerpt from Levi ben Gershon's discourse on Jacob's staff, a tool used to measure the height of the stars. This instrument was later adopted by Portuguese explorers. 68 Much of Clement VI's interests in astronomy was a sideline to his desire to reform the calendar. In addition to his interests in music, Jehan de Murs was a great mathematician. It was in Jehan de Murs and Firminus of Bellavalle that Clement VI posited his hopes to reform the Julian calendar. ${ }^{69}$ Their efforts in this area generally came to nothing.

Clement VI's humanistic ideals, manifested through papal patronage, are fairly discernable. Several men commonly associated with the early Renaissance spent some time in Clement VI's court. If one holds with the spanish proverb, "Tell me with whom you live, and I will tell you who you are," then perhaps Clement VI was the first Renaissance pope. ${ }^{70}$ Some commentators of his day acknowledged his humanity, noting not only generosity and

${ }^{68}$ Thorndike, 20 .

${ }^{69}$ Thorndike, 19.

${ }^{70}$ Tryon Edwards, ed., The New Dictionary of Thoughts (New York: Standard Book Company, 1966), 34. 
liberality, but also his lavishness and eloquence. ${ }^{71}$ Many modern scholars have also lauded him as the progenitor of a thirteenth century proto-Renaissance. Antoine Pelissier called him "le Magnifique," in the title of his book.

Anneliese Maier described him as "der Humanistenpapst des 14 Jahrhunderts." 72 John Wrigley, the foremost scholar on the life of Clement VI, said that he embodied the "spirit of humanism. $" 73$

On the opposite side of the coin, Kurt Huber while agreeing that $C l e m e n t ~ V I$ was more secular minded than most of his predecessors, pointed to Clement's "theological commitments and... insight into mystical literature." 74 Bernard Guillemain noted these inharmonious characteristics and questioned how original a thinker Clement VI really was. ${ }^{75}$

The truth appears to lie somewhere in the middle. Given the state of affairs and the legacies of earlier

${ }^{71}$ Wood, 4-5.

${ }^{72}$ Anneliese Maier, "Zu Walter Burleys Politik-Kommentar," Ausgehendes Mittelalter gesammelte Aufsatze zur Geistesgeschichte des 14 Jahrhunderts vol. 1, (Rome: 1964), 99, in Wood, Ideas and Pontificate, 1.

${ }^{73}$ John E. Wrigley, "Studies in the Life of Pierre Roger (Pope Clement VI) and of Related Writings of Petrarch," (Ph.D. diss., University of Pennsylvania, 1965), liii.

${ }^{74} \mathrm{~K}$. A. Huber, "Clement VI. (Pierre Roger)," in Seibt, ed., 1978, 108, in Wood, 4.

${ }^{75}$ Bernard Guillemain, "Clemente VI, "Dizionario Biografico degli Italiani 26 (Rome: 1982): 216, in Wood, 4. 
pontificates, it is obvious that clement VI was cut from a different cloth. His reign was more akin to the secular minded Renaissance popes Leo $X$ or Paul III, than to the earlier Avignonese popes John XXII or Benedict XII. His theological and academic training, however, were grounded in medieval scholasticism. The middle ground seems to occur in the personality of the man.

\section{Clement VI was most familiar with the feudal}

arrangement of things and his papacy illustrates this point. He was also very aware of the precarious position of the papacy, it being both absent from its patrimony of Rome and accused of being the lackey of the French king. What was needed was a strong pope, one unafraid to assert his power. Clement VI evidently recognized that ostentatious accoutrements were necessary if the papal court was to command the respect of the great monarchs of Europe. Simply put, the resources were there and Clement VI was spendthrift enough to use them.

In conclusion, we must surmise that clement VI was a transitional figure, imbued with great intellectual and oratorical skills, but lacking the intensity of commitment essential to the humanistic vision of the Italian Renaissance. Clement VI's liberality and relish for the finer things in life should not be confused with the grandiose intentions of the fifteenth century princely popes. His life was grounded in the church. His appreciation of the classics drew from the same insatiable 
curiosity and passion for learning that fired his love for traditional devotional works. All the elements which we associate with the Renaissance in Italy simply had not coalesced by the $1340^{\prime} \mathrm{s}$ in France. In the final analysis, Clement VI's role must be recognized as a bridge to the Renaissance. 
CONCLUSION

No matter how forcefully Clement VI tried to reinvigorate the papal monarchy, he was bound to fail. The dislocations of the fourteenth century were such that no man nor idea alone could correct them. While the role of the Hundred Years' War and the Black Death have not been represented fully in this research, they dictated, to a large part, the degree of success or failure for many of clement's projects. The papal monarchy at its height in the thirteenth century would have struggled to match the massive upheavals of the fourteenth century. Fifty years later, the Church was still vexed by the confrontation between King Philip IV and Boniface. To elevate the papacy to monarchy would have required bold and creative strokes; clement, however, relied on time-tried correctives. There was nothing especially new in his approach. While clement truly possessed one of the great minds of his age, it was tempered by a conservatism that precluded a great deal of innovation. His political intrigues, his crusading achievements, and the vitality of his papal court, all indicate that he was capable of wielding power with vitality, but little restraint.

The attack on the papacy at Anagni in 1303 forced it to become more aware of secular independence. The tenure of the papacy at Avignon, while in many senses short on spiritual fervor, witnessed the growth of a bureaucracy 
highly capable of adapting to the changing political panorama of the fourteenth century. While decidedly French, the ecclesiastical administration grew under Pope clement VI's command. This growth was the result of necessity, not luxury. The conflict between the French and the English, the warring among the disparate Italian factions, and the theological controversies of the time, stretched the resources of Clement's already strained papal administration.

There could have been no talk of crusade or humanistic rebirth in Avignon during Clement's reign had the papal organization been powerless. The efforts to reinvigorate the papacy, begun by John XXII and continued by Benedict XII, achieved a degree of fruition under clement. His beneficence increased the status of the pope, but at great cost. The lavishness and generosity of clement's papacy had to be paid for eventually by someone. The next two popes were reduced to penurious conditions. The lofty heights to which Clement aspired were brought low by the poverty and privation that ensued with the election of his successor, Innocent VI. Innocent was reduced to selling off much of the art and riches that $\mathrm{Clement}$ had amassed. Rather than strengthening the papacy, Clement weakened it to the point that it was unable to defend itself when the marauding Free Companies of the Hundred Years War arrived in Avignon.

The height of the papal monarchy in the thirteenth century was an irretrievable ideal by the mid-fourteenth 
century. The arguments that had been successfully employed to elevate the papacy in prior centuries had been stretched to their greatest logical extent by clement's time. The hierocratic theory was too worn out and monolithic to contest the changing realities of the times. Clement's ultramontanist views were not shared by a large number of people outside of the Church. Thus, we see a growing sense of secular "nationalism" increasingly displacing papal authority in areas where the papacy had previously held dominion.

While clement may have failed in his quest to become a papal monarch, he did expand the pope's universal role as the prince of the Church. His liberal efforts in the area of papal provisions and benefices helped to centralize papal control over churches and diocese throughout Europe. Coupled with this centralization was an attempt to claim larger domains for the Church. Clement sent frequent embassies to Constantinople in hope of resolving the schism. He also worked toward the strengthening the role of the Church in eastern Europe. All these efforts enhanced his position.

Petrarch called Avignon the Babylon of the West after having spent a great deal of time at clement's court. Undoubtedly, Petrarch was echoing the sentiment held by many of the spiritualists and mystics of the time, who believed that clement had sacrificed too much spiritual power in trying to gain earthly power. Did Clement believe 
that he could buy the respect and allegiance of Christians by means of ostentatious generosity? It is easy to arrive at this conclusion if Petrarch's words are accepted without question. Clement was no saint. Rather, he realized that his theoretical basis for authority, while potent, was no substitute for real power. He had witnessed first hand how the French monarchs had amassed such great power just prior to the war with England. By adopting a more ultramontane attitude, the papacy too, could regain its prior eminence. In the perilous years of the mid-fourteenth century, the force of Clement's character alone, was insufficient to restore the papal monarchy. 


\section{GLOSSARY}

Auctoritas - Auctoritas connotes the idea of rights conferred. The popes of the Middle Ages claimed auctoritas as the attribute which elevated their position above all secular and ecclesiastical leadership. This auctoritas was said to have been conferred by Jesus Christ upon Peter, and then was claimed by his successors in Rome.

Caesaro-papism - The theory of government by which the exercise of royal and sacerdotal power are vested in a single person. This idea came from the classical Roman model where the emperor controlled both offices. The church attempted unsuccessfully to deal with caesaropapism at the council of chalcedon in 451. The Byzantine East accepted this idea, the greatest examples being Justinian and zeno. It never held much weight in the west after the fall of Rome.

Imperium - Imperium is the right to command authority. It had a combined meaning in the Roman Empire: the right to rule in laws, and the right to rule in military affairs. A medieval interpretation stated that the Holy Roman Emperor held imperium from the original Roman emperors. It was based on the idea of universality and autonomy.

Maiestas - This term means greatness, grandeur, or dignity. It was often used with the idea of imperium. It is by one's greatness that a person is able to wield power.

Peregrinator - This Latin term originally applied to travellers in general. During the Crusades, it took on a sense of religious pilgrimage. Peregrinatores were often knights, whose mission it was to retake the Holy Land.

Potestatis - Potestatis simply means power. In this research, it had both temporal and sacerdotal affiliations. The emperor claimed his power as a legacy from his successors, and held it de facto. The pope claimed plenitudo potestatis, which gave him the right of command in both the religious and secular arena. The pope may wield this power or may delegate it to another as agent, to be enforced by his supreme direction (ad nutum). This power was theoretical. 
WORKS CITED

Aegidius Romanus. De Ecclesiastica Potestate. Edited by $R$. Scholz. Weimar, 1929.

Anonymous. The Deeds of the Franks and the other Pilgrims to Jerusalem. New York: Thomas Nelson and Sons, 1962 .

Aristotle. Politica, in The Works of Aristotle. Translated by Benjamin Jowett. New York: Oxford University Press, 1952 .

Atiya, A. S. The Crusade in the Later Middle Ages. New York: Kraus Reprints, 1965.

Baluzius, S. Vitae Paparum Avenionensium. Edited by Guillaume Mollat. Paris, 1914-27.

Barraclough, Geoffrey. The Medieval Papacy. New York: W.W. Norton, 1968.

Brooke, Christopher. The Twelfth Century Renaissance. New York: Harcourt, Brace \& World, 1969.

Brucher, Gene A. Renaissance Florence. Berkeley, California: University of California Press, 1969.

Burckhardt, Jakob. The Civilization of the Renaissance in Italy. New York: Random House, 1954.

Burnham, Philip, E. "The Patronage of Clement VI." History Today 27 (1978): $372-81$.

Burns, J. H., ed. The Cambridge History of Medieval Political Thought. Cambridge: Cambridge University Press, 1988 .

Canning, Joseph. The Political Thought of Baldus de Ubaldis. New York: Cambridge University Press, 1987.

Cantor, Norman F., ed. The Medieval World: 300-1300. New York: Macmillian Co., 1963.

Carlyle, R.W., and A.J. Carlyle. A History of Medieaval Political Theory in the West. Vols. 1-6, London: William Blackford \& Sons, 1903-36. 
Chaucer, Geoffrey. The Canterbury Tales., Translated by Nevill Coghill. Baltimore: Penguin Books, 1957.

Cosenza, Mario, E. Petrarch: The Revolution of Cola di Rienzo. Ithaca, New York: Ithaca Press, 1986.

Depres, Eugene., ed. Clement VI: Lettres closes, patentes et curiales se rapportant a la France. (1901-61).

- Lettres closes, patentes et curiales interresant les pays autres que la France. eds. E. Deprez and G. Mollat, Paris, 1960-1.

Ehrle, F. Historia Bibliothecae Romanorum Pontificum. Rome, 1890 .

Einhard and Nottker the stammerer. Two Lives of Charlemagne. Edited by Betty Radice. New York: Viking Penguin, 1969.

Faucon, Maurice. "Prets faits aux rois de France par Clement VI, Innocent VI et le comte de Beaufort (1345-60)", Bibliotheque des Ecoles des Chartes, 60 (1879): 570-8.

Flick, Alexander. Decline of the Medieval Church. New York: Alfred A. Knopf, 1930 .

Froissart. Chronicles. Edited by Betty Radice. New York: Viking Penguin, 1987.

Gay, Jules. Le Pape clement VI et les affaires d'orient. New York: Burt Franklin Press, 1972.

Gewirth, Alan. Marsilius of Padua: The Defender of Peace. New York: Columbia University Press, 1956.

Gierke, otto. Political Theories of the Middle Ages. Translated by F.W. Maitland. New York: Cambridge University Press, 1927.

Giles, E., ed. Documents Illustrating Papal Authority, A.D. 96-454. London: William Clowes and Sons, 1952.

Gill, Joseph Byzantium and the Papacy: 1198-1400. New Brunswick, N.J.: Rutgers University Press, 1979.

Guillemain, Bernard. La Cour Pontificale D'Avignon: 13091376. Paris: Editions E. de Boccard, 1966.

Heft, James. John XXII and Papal Teaching Authority. Text and studies in Religion, vol. 27 Lewiston, N.Y.: Edwin Mellen Press, 1986. 
Housley, Norman. The Avignon Papacy and the Crusades, 1305-1378. Oxford: Clarendon Press, 1986.

Jarrett, Bede. The Emperor Charles IV. New York: Sheed \& Ward, 1955 .

Kelly, J. N. D. The Oxford Dictionary of Popes. New York: Oxford University Press, 1989.

Lewis, Ewart. Medieval Political Ideas. London, 1954.

Livy. The Early History of Rome. Edited by Robert Baldick New York: Viking Penguin, 1974.

Lutrell, Anthony. "The Crusade in the Fourteenth Century", Evanston, Ill.: Northwestern University Press, 1965, $122-54$.

Maier, Anneliese. "Der Literarische Nachlass des Petrus Rogerii." In Ausgehendes Mittelalter, 255-315. Rome, 1967 .

Mayer, Hans, E. The Crusades. Translated by John Gillingham, New York: Oxford University Press, 1988.

McIlwain, Charles H. The Growth of Political Thought in the West. New York: Macmillian, 1963.

Mollat, Guillaume. The Popes at Avignon: 1305-1378. Translated by Janet Love New York: Thomas Nelson and Sons, 1963.

Ostrogorsky, George. History of the Byzantine state. rev. ed., Translated by Joan Hussey New Brunswick, N.J.: Rutgers University Press, 1969.

Oxford Annotated Bible. rev. ed., Edited by Herbert G. May and Bruce M. Metzger, New York: Oxford University Press, 1962 .

Pelissier, Antoine. Clement VI: le Magnifique. Brive, France: Imprimerie Lachaise, 1950.

Peter of Herenthals, "Vita Clementis VI." In Vitae Paparum Avenionensium. Edited by S. Baluze, 303-451. Paris, 1914-1927.

Pirenne, Henri. Economic and Social History of Medieval Europe. New York: Harcourt, Brace \& World, 1937.

Plumb, J. H., The Italian Renaissance. New York: Harper and Row, Publishers, 1961. 
Renouard, Yves, Les Relations des Papes d'Avignon et des Compagnies Commerciales et Bancaires de 1316-1378, Paris: Bibliotheque des Ecoles Francaises d'Athenes et de Rome, 1941.

- The Avignon Papacy. Translated by Denis Bethell, Hamden, Conn.:Archon Books, 1970.

Riesenberg, P. N., Inalienability of Sovereignty in Medieval Political Thought, New York, 1956

st. Augustine. Enarrationes in Psalmos. Westminster, Maryland: The Newman Press, 1960.

st. Thomas Aquinas. Summa Theologicae. In Basic Writings of Saint Thomas Aquinas. Edited by A. C. Pegis. New York: Random House, 1945.

Setton, Kenneth M. gen. ed., A History of the Crusade. Madison, Wisconsin: University of Wisconsin Press, 1975.

- The Papacy and the Levant. vol. 1, The Thirteenth and Fourteenth Centuries. Memoirs of the American Philosophical Society, no. 114, Philadelphia: The society, 1976 .

Simone, Franco. The French Renaissance. Medieval Tradition and Italian Influence in shaping the Renaissance in France. Translated by H. G. Hall, London, 1969.

Southern, Richard $w$. Western society and the church in the Middle Ages. New York: Viking Penguin, 1983.

Stubbs, William. Germany in the Later Middle Ages:1200-1500. Edited by Arthur Hassall New York: Howard Fertig, 1969.

Synan, E. A. The Popes and the Jews in the Middle Ages. New York: Harper \& Row, 1965 .

Tacitus. The Annals of Imperial Rome. rev. ed., Edited by Betty Radice, Translated by Michael Grant New York: Viking Penguin, 1989.

Thorndike, Lynn. Science and Thought in the Fifteenth Century. New York: Hafner Publishing Company, 1963.

Tierney, Brian. The Crisis of Church and State: 1050-1300. Englewood Cliffs, N.J.: Prentice-Hall, 1964. - Origins of Papal Infallibility: 1150-1350. Leiden, Netherlands: E. J. Brill, 1972. 
The Middle Ages, vol. 1: Sources of Medieval

History. 4th ed., New York: Alfred A. Knopf, 1983.

Tomasello, Andrew. Music and Ritual at Papal Avignon: 1309-1403. Ann Arbor, Michigan: UMI Research Press, 1983 .

Ullmann, Walter. The Papacy and Political Ideas in the Middle Ages. London: Variorum Reprints, 1976.

Vasari, Giorgio. Lives of the Artist. trans. George Bull, New York: Penguin Books, 1965.

Wilkins, Ernest, Hatch. Studies in the Life and Works of Petrarch. Cambridge, Massachusetts: Crimson Printing Company, 1955.

Wilks, Michael. The Problem of Sovereignty. New York: Cambridge University Press, 1964

Wood, Diana. "... novo sensu sacram adulterare Scripturam: Clement VI and the political use of the Bible" in The Bible in the Medieval World: Essays in the Memory of Beryl Smalley. Edited by $K$. Walsh and Diana Wood, Studies in Church History. subsidia 4 (1985): 237-49.

- Clement VI, the Pontificate and Ideas of an Avignon

Pope. New York: Cambridge University Press, 1989.

Wrigley, John, E. "A Papal Secret Known to Petrarch." A Journal of Medieval Studies. vol. 39, no. 4 (October, 1964): 613-34.

. "A Rehabilitation of Clement VI: Sine Nomine 13 and the Kingdom of Naples." Archivum Historiae Pontificae. 3 (1965): 127-38.

. "Clement VI Before His Pontificate: The Early Life of Pierre Roger, 1290/91-1342." The Catholic Historical Review. 55 (October, 1970): 433-73. 


\section{VITA}

The author, Henry Miles Spalding, is the son of Dr. Henry S. Spalding and Martha (Edelen) spalding. He was born April 19, 1961, in Bardstown, Kentucky.

His elementary education was obtained at St. Joseph Elementary School, and secondary education at Bethlehem High School, both in Bardstown, Kentucky, where he was graduated in 1979.

In January, 1983, he entered the University of Louisville, and in May, 1989, received the degree of Bachelor of Arts with a major in history. While attending the University of Louisville, he was secretary and historian of the University of Louisville's chapter of Phi Alpha Theta.

In December, 1992, he was awarded the Master of Arts in History.

Henry Miles Spalding is married to Melissa (Shore) spalding. He has one daughter, Anna Catherine spalding. 